\title{
Spatial estimates of snow water equivalent from reconstruction
}

\author{
Karl Rittger $\underline{\mathrm{a}}$, Edward H. Bair $\underline{\mathrm{b}}$, Annelen Kahl $\underline{\mathrm{c}, 1}$, and Jeff Dozier $\underline{\mathrm{c}}$ \\ a National Snow and Ice Data Center, University of Colorado, Boulder CO 80309-0449, USA, \\ karl.rittger@nsidc.org, 303-735-3433 \\ b Earth Research Institute, University of California, Santa Barbara CA 93106-3060, USA, \\ nbair@eri.ucsb.edu \\ $\subseteq$ Bren School of Environmental Science \& Management, University of California, Santa Barbara \\ CA 93106-5131, USA, dozier@ucsb.edu \\ 1Present Address: EPFL Laboratory of Cryospheric Sciences, Ecole Polytechnique Fédérale de \\ Lausanne, CH-1015 Lausanne, Switzerland, annelen.kahl@epfl.ch
}




\begin{abstract}
Operational ground-based measurements of snow water equivalent (SWE) do not adequately explain spatial variability in mountainous terrain. To address this problem, we combine satellite-based retrievals of fractional snow cover for the period 20002012 with spatially distributed energy balance calculations to reconstruct SWE values throughout each melt season in the Sierra Nevada of California. Modeled solar radiation, longwave radiation, and air temperature from NLDAS drive the snowmelt model. The modeled solar radiation compares well to ground observations, but modeled longwave radiation is slightly lower than observations. Validation of reconstructed SWE with snow courses and our own snow surveys shows that the model can accurately estimate SWE at the sampled locations in a variety of topographic settings for a range of wet to dry years. The relationships of SWE with elevation and latitude are significantly different for wet, mean and dry years as well as between drainages. In all the basins studied, the relationship between remaining SWE and snow-covered area (SCA) becomes increasingly correlated from March to July as expected because SCA is an important model input. Though the SWE is calculated retrospectively SCA observations are available in near-real time and combined with historical reconstructions may be sufficient for estimating SWE with more confidence as the melt season progresses.
\end{abstract}

\title{
Key Words
}

Snow, remote sensing, spatial distribution, Sierra Nevada, NLDAS, MODIS. 


\section{Introduction}

In the Sierra Nevada of California, most streamflow comes from snowmelt, and in most basins the reservoirs hold little more than average annual runoff, for example the Kings River basin with an April to July runoff volume of $1.3 \mathrm{~km}^{3}$ and a total reservoir volume of $1.53 \mathrm{~km}^{3}$. Point measurements of snow water equivalent (SWE) from snow pillows and transects from snow courses remain the primary source of data about the snow, but those data may not correctly represent the spatial and temporal variability in mountainous terrain. Significant areas lie above the highest snow pillows and courses, which monitor neither moderate nor steep slopes. Knowing the spatial distribution of SWE is necessary to reasonably estimate the partition of snowmelt between evapotranspiration, quickflow, percolation to the ground water, and streamflow. If water managers better understood the distribution of snow and its melt rate, they could better deal with the competing priorities for flood protection and resource provision for cities, industries, agriculture, hydropower and ecosystems.

Two separate entities, the NOAA/NWS California Nevada River Forecast Center (CNRFC) and the California Department of Water Resources (CADWR), work together but produce their own forecasts of seasonal runoff by multiple linear regression of streamflow against snow pillows and courses [1, 2]. In addition, NOAA/NWS uses the same information along with a numerical model to produce weekly ensemble forecasts. Historical predictions of seasonal runoff have been inaccurate in both wet and dry years [3], partly because the measurement network provides few data about SWE at the highest elevations, and snow courses and pillows are all on nearly flat terrain. Decreasing snow accumulation and earlier snowmelt runoff $[4,5]$ make forecasting a challenging problem because the statistical environment is not stationary [6], so a more mechanistic way of estimating seasonal runoff is needed. Moreover, knowledge 
of the spatial distribution of snow will help inform the effects of snowmelt on soil moisture and vegetation. Projected changes in runoff during the lifetime of major water infrastructure are large enough to exceed the range of historical behavior [7].

We address the following questions: (1) How well can the spatial distribution of SWE in the mountains be estimated using space-based remote sensing to reconstruct the post-peak snow accumulation? (2) How strong is the seasonal relationship of SWE to elevation in the Sierra Nevada? (3) How does this relationship differ between basins and among years? (4) What is the relationship between snow-covered area (SCA) and SWE and can SCA be used to estimate basin wide SWE?

Section 2 describes the characteristics of the Sierra Nevada and its basins. Section 3 describes the reconstruction model, the data used to drive the model, and downscaling methods used to distribute the energy balance. In the absence of any method to directly measure SWE over large mountain ranges, reconstruction appears to be the most reliable way to estimate its spatial distribution [8]. Section 4 assesses error and uncertainty in energy balance components, using ground observations where available and a model that couples energy and water balances where observations are not available. Section 5 compares SWE from the reconstruction model with snow snow courses and snow surveys. Section 6 explores the relationship of SWE with elevation, latitude and snow covered area.

\section{Study area}

The Sierra Nevada maritime snowpack lies primarily in California and encompasses four major drainages (Figure 1a) within which full natural flow calculations are available in 18 smaller hydrologic unit code 8 (HUC8) basins (Figure 1b). Those in the Sacramento and San Joaquin drainages cover 17,560 
$\mathrm{km}^{2}$ and $17,710 \mathrm{~km}^{2}$, while those in the Tulare and Lahontan cover $12,590 \mathrm{~km}^{2}$ and $5,730 \mathrm{~km}^{2}$. Table 1 shows areas and minimum, mean, and maximum elevations for each HUC8 basin. Basins in the Tulare drainage generally have higher elevations than those in the Sacramento or San Joaquin, while Lahontan basins have the highest elevations but lie on the lee side of the Sierra Nevada. HUC8 basins in the Sacramento, San Joaquin and Tulare drainages drain toward the southwest, with the exception of the Kern that flows southward, while the Lahontan basins drain northeast except for the Owens, which drains toward the south.

Table 2 summarizes the primary forms of vegetation in the Sierra Nevada derived from the LANDFIRE dataset's existing vegetation type [9]. Coniferous forest is the primary form of vegetation for every basin except the East Walker in the Lahontan, which has more shrubs than trees. In general, the basin forest cover fraction decreases from north to south, as bare soils, rock outcrops and shrubs are more common at the highest elevations more prevalent in the south.

There is extensive monitoring of snow through snow pillows and courses, as Figure 1a shows. The Sacramento drainage is the most highly instrumented, while the Lahontan is the least instrumented. Even with extensive monitoring, there is a lack of information about the highest elevations throughout the season.

Figure 2 illustrates the consequences of this lack of information. It shows fractional snow covered area from the Landsat Thematic Mapper (TM) on July $2^{\text {nd }}$ and July $18^{\text {th }}, 2011$ in the Tuolumne and Merced River basins. On these days significant snow existed at the high elevations, and between the two dates the snow covered area decreased, producing significant melt. Figure $2 c$ shows the snow pillow observations throughout the season. On July $2^{\text {nd }}$, only two snow pillows, STR (8200 m) and VRG (9300 m) registered any snow and on the July $18^{\text {th }}$ all snow pillows were bare including the two other moderately high elevation snow pillows, SLI (9200 m) and (DAN $9800 \mathrm{~m}$ ). A forecast of streamflow that relied on these observations would likely underestimate the 
likely amount of snow still to melt without the areal information shown in Figure 2 ( $a$ and $b$ ). This lack of information is problematic for the late melt season shown here. At maximum accumulation, the same problem exists and the volume of SWE stored above the snow pillows is an unknown.

\section{Reconstruction of snow water equivalent}

\subsection{Reconstruction method}

First implemented by Martinec and Rango [10], the reconstruction uses the satellite-derived snow cover depletion record of the melt rate to retroactively estimate how much snow had existed at every pixel. The technique has been validated in the Sierra Nevada [11] and applied to large basins at multiple scales[12,13]. Recent work comparing forward based modeling and reconstruction suggests that in areas with high precipitation uncertainty, reconstruction provides the best approach for SWE estimation[14]. In the Merced and Tuolumne River basins, the snow depletion from reconstruction better matches observed streamflow than interpolation utilizing the snow pillow measurements [15]. The widely used SNODAS model performs poorly compared either to reconstruction or interpolation [16].

We combine both energy balance and temperature index methods to model SWE where the following equation is the basis for reconstruction:

$$
S W E_{N}=S W E_{0}-\sum_{j=1}^{N} M_{j}
$$

$S W E_{0}$ is the initial SWE, at maximum for each pixel, $S W E_{N}$ is the SWE after a series of $N$ melt steps $M_{j}$,

$$
M_{j}=M_{P, j} \times f_{S C A, j}
$$


$M_{p j}$ is the potential melt at time step $j$ and $f_{S C A, j}$ is the fractional snow-covered area at time step $j . M_{p j}$ is calculated with a combined energy balance, temperature index model [17]:

$$
M_{P, j}=m_{Q} R_{d}+\beta_{r} T_{d}
$$

$m_{Q}$ is the conversion factor from energy to melt $\left(0.26 \mathrm{~mm} \mathrm{day}^{-1}\right.$ per $\left.\mathrm{W} \mathrm{m}^{-2}\right), R_{d}$ is the mean daily net radiation $\left(\mathrm{W} \mathrm{m}^{-2}\right), \beta_{r}$ is a degree day factor, and $T_{d}$ is the mean daily temperature above $0^{\circ} \mathrm{C}$. For $\beta_{r}$ we use a common value from the literature of $1.5 \mathrm{~mm} \mathrm{deg}^{-1} \mathrm{day}^{-1}[12,17]$. This degree day factor could be calculated with the reanalysis data, however wind speeds from reanalysis are likely to have large errors, and earlier studies have found model performance depends less on the degree day factor when solar and longwave radiation are used in addition to temperature [17]. In the Sierra Nevada's Tokapah basin located in the Kaweah River basin, turbulent fluxes accounted for only $10 \%$ of total melt [18]. For each year, SWE at its seasonal maximum is created by summing the melt rate from each pixel's date of maximum SWE, calculated from an interpolation of snow pillows, through the day that $f_{S C A}$ for that pixel goes to zero. The interpolation is elevation based and uses Theissen polygons to determine which snow courses and snow pillows are used in the interpolation for each individual basin. Figure 3 shows the $10^{\text {th }}$ percentile, mean, and $90^{\text {th }}$ percentile dates of maximum SWE for the 12-year period. In general, drier years have earlier maximum SWE, wetter years later. Although April $1^{\text {st }}$ is often thought of as the peak SWE date, Figure 3 shows significant spatial and interannual variability. Small snowfall events after peak SWE can extend the snow cover later in the season, increasing uncertainty in the estimates. For larger snowfall events after peak SWE, the reconstruction can overestimate peak SWE, but it is worth noting that melt from those events contribute to streamflow. 
The 12-year period used in this study captures a large range of variability. Figure 4 shows reconstructed SWE for a dry year (2007) and a wet year (2011). On April $1^{\text {st }}$ over much of the Sierra Nevada, 2007 SWE is below $750 \mathrm{~mm}$ while in 2011 SWE is greater than $2000 \mathrm{~mm}$. Moreover, the Sierra has more snow on July $1^{\text {st }} 2011$ than two months earlier in 2007.

Previous work on spatial scaling of snow processes indicates that modeling solar and thermal inputs at grid sizes greater than $250 \mathrm{~m}$ can introduce biases, particularly in the melt season, and that $100 \mathrm{~m}$ grid scale modeling of energy fluxes produces results much like $30 \mathrm{~m}$ scale, adequate for runoff forecasting [19]. Therefore, in this study we set the modeling resolution at $100 \mathrm{~m}$.

\subsection{Snow cover and albedo}

Snow albedo is frequently modeled with an age-based relationship [20, 21]. However, a simple age decay curve does not account for albedo varying both temporally and spatially, depending on topography [22]. Moreover, as time passes, dust and black carbon deposit onto the snow and lower the albedo, increasing the net radiation in the spring. The processes by which albedo changes complicate our ability to model those changes. Grain growth, which causes albedo to decrease in the near-infrared, depends on processes that occur in the snowpack and thus is amenable to modeling based on snowpack temperatures and their gradients [23] but contamination by dust or soot is independent of anything going on in the pack and thus must be measured [24].

For our reconstruction model, snow covered area and grain size are derived from Moderate Resolution Imaging Spectroradiometer (MODIS) data using the MODSCAG model [25]. The albedo of pure snow is fit to an empirical relationship with grain size and illumination angle. Contamination by dust or soot is less common in the Sierra Nevada than in the Rocky Mountains [26]. The MODIS reflectance data (product MOD09GA) have gaps and errors because of cloud cover, noise, and sensor viewing geometry, so we filter, interpolate, and smooth 
the time series to produce a best estimate of daily snow cover and albedo [27]. We adjust the satellite-observed snow cover for snow under the canopy $[12,28]$ by each pixel's vegetation cover, thereby accounting for forests and for shrubs and grass that are uncovered as the snow recedes.

Figure 5 shows the a) minimum, b) mean, and c) maximum albedo for April 1 for the period of study (2000-2011) in locations where snow is persistent (i.e. median snow cover fraction $>0$ ). Alpine regions have the highest albedo in general while forested areas have lower albedo, possibly from surface debris [29]. In Figure 5b the higher albedo right at the snow line is an artifact. If the $500 \mathrm{~m}$ pixel contains rock (or dust/dirt on the snow), the combination of the snow and rock reflectance lowers the visible reflection and increases the nearinfrared reflectance compared to the reflectance of a pure snow pixel. MODSCAG uses the spectral shape, not the absolute albedo, so the difference between the visible and near infrared reflectance is reduced and the relative shape of the snow spectrum appears similar to fine grain snow.

The histograms in Figure 5 show distributions of albedos that range from 0.65 to 0.85 . Old, dirty snow can have an albedo as low as 0.4 [20]; shallow mountain or prairie snowpacks can reach 0.3 or lower [30, 31]. However, minimum snow albedo derived from MODSCAG for the 12-year record is 0.65 even when we consider May and June. The relatively high albedo values indicate that MODSCAG overestimates snow albedo possibly from impurities and mixed pixels as described above. To account for these impurities we apply a scalar decrease to the snow albedo of $12 \%$. The model does not track new snowfall events, making implementation of the models based on snow age difficult, especially given the accuracy of aging models when compared to actual measurements [32]. Snow course observations described in 5.1 were used to find the optimal value for this calibration. Sensitivity analysis of SWE indicates that a scalar decrease of $11 \%$ (i.e. 1\% less than used in this study) would result in mean difference for $S W E_{0}$ of $12 \mathrm{~mm}$ across the study region. Albedo 
observations from the Mammoth Mountain instrument site in 2014 show a similar bias $[33,34]$.

Other available MODIS derived albedo include MOD10A1 [35] but the product applies only where snow is the dominant surface, which is problematic given the forest cover in the study area. We suggest using MCD43 [36] that is currently available at 16-day intervals; however the snow surface changes daily. New products that account for the effect of dust on snow from the MODIS Dust Radiative Forcing of Snow (MODDRFS) algorithm may capture the spatial heterogeneity of the dust forcing [37] not accounted for by the scalar adjustment made here. To be useful this product needs to be combined with clean snow albedo and interpolated in time and space, a difficult task because MODDRFS is only valid on regions that are free of mixing (i.e. less than $5 \%$ vegetation in a $500 \mathrm{~m}$ pixel). While a scalar adjustment inherently has problems, MODSCAG currently provides the cutting edge of albedo observation for mixed pixels; modeling the snow albedo would likely result in larger errors as compared to measured albedo in the Sierra Nevada [33].

Snow covered area and albedo were not available from MODIS before March 2000. Accumulation at snow pillows for 2000 best matched January 2001 and February 2008 so snow cover and albedo from those years were used in place of the missing data. This substitution's expected error should be minor, as most of the snow pillows reached their maximum after March $1^{\text {st }}$ in 2000.

\subsection{Air temperature}

The reconstruction relies on a digital elevation model from the Shuttle Radar Topography Mission (SRTM) that has an absolute height error of less than $16 \mathrm{~m}$ [38]. The interferometric radar method misses elevations in extreme topography, mostly steep river channels, and these holes in the data are filled with elevations from the National Elevation Dataset [39]. The merged SRTM/NED elevations are resampled to $100 \mathrm{~m}$. Air temperature $T_{A}$ was 
downscaled from $1 / 8^{\circ}$ NLDAS2 reanalysis data [40] to $100 \mathrm{~m}$ grid cells using an environmental lapse rate of $-6.5^{\circ} \mathrm{K} / \mathrm{km}$. In the reconstruction model, the mean daily temperature is calculated for each pixel. Station data in the Sierra Nevada over multiple years show that the typical environmental lapse rate used in this study represent average conditions $[15,41]$. The topographic variability of temperature depends on atmospheric circulation patterns [41], but in the Sierra Nevada solar radiation affects snowmelt more than air temperature does [42].

\subsection{Solar radiation}

Net solar radiation $Q_{n s}$ is the difference between incoming and outgoing solar radiation $S_{\downarrow}$ and $S_{\uparrow}$. Incoming solar radiation $S_{\downarrow}$ is comprised of beam $B_{S \downarrow}$ and diffuse $D_{S \downarrow}$ radiation from the sun, and reflected radiation $R_{T \downarrow}$ from surrounding topography. Topography affects these fluxes because of variation in illumination angle and shadowing from local horizons. Incoming solar radiation on a horizontal surface from NLDAS2 $[40,43]$ is partitioned into $B_{S \downarrow}$ and $D_{S \downarrow}$ using transmittance $T$, exoatmospheric solar radiation $S_{0}$ and $\mu_{0}$, the cosine of the solar zenith angle. Transmittance $T$ is:

$$
T=\frac{S_{\downarrow}}{\mu_{0} S_{0}}
$$

The partitioning formula [44] has been modified for mountainous terrain [45] and uses distinctive relationships between $S_{\downarrow}$ and $T$ to determine the beam and diffuse irradiance for cloud, partly cloudy and clear days. Another partitioning formula was tested [46] because of its simplicity and use in other snow studies [29], but it produced an unreasonably large diffuse fraction on clear days.

Figure 6a shows $S_{\downarrow}$ for noon on May 24th 2006 over the Tuolumne and Merced River basins. Both the incoming beam $B_{S \downarrow}$ and diffuse $D_{S \downarrow}$ solar radiation are approximated with a spatially averaged beam $\overline{B_{x \downarrow}}$ and diffuse downwelling $\overline{F_{x \downarrow}}$ flux centered on grid cell $x$, adjusted to elevation $z$ [47] and corrected with a 
sky view factor $V_{d}$ [48]. $\theta_{i}$ is the solar illumination angle on the slope and $\delta$ is a binary shadowing mask:

$$
\begin{gathered}
B_{S \downarrow}=\delta \cos \theta_{i} \overline{B_{x \downarrow}}(z) \\
D_{S \downarrow}=\overline{F_{x \downarrow}}(z) V_{d}
\end{gathered}
$$

Both $\overline{B_{x \downarrow}}$ and $\overline{F_{x \downarrow}}$ are estimated by spatially averaging the partitioned NLDAS2 incoming radiation in a neighborhood centered on the $100 \mathrm{~m}$ DEM with a Gaussian filter and a $40 \mathrm{~km}$ neighborhood. Figure $6 \mathrm{~b}$ shows the sum of $\overline{B_{x \downarrow}}$ and $\overline{F_{x \downarrow}}$ for noon on May $24^{\text {th }}, 2006$. Optical depths $\tau_{0}$ at the NLDAS2 grid cell elevation are derived from $\overline{B_{x \downarrow}}$, along with Earth-Sun distance $R_{v}$ in astronomical units and the atmospheric airmass $a$ including refraction [49].

$$
\tau_{0}=-a^{-1} \ln \left(\frac{\overline{B_{x \downarrow}} R_{v}{ }^{2}}{\mu_{0} S_{0}}\right)
$$

The formula for airmass includes temperature and pressure. Temperatures were downscaled from $1 / 8^{\circ}$ using a standard environmental lapse rate, as Section 3.3 describes. NLDAS2 pressures were downscaled with the hydrostatic equation and density. Then the optical depth $\tau_{z}$ at elevation $z$ is estimated assuming a pressure-dependent decrease in direct transmittance. The elevation corrected solar radiation is:

$$
B_{z \downarrow}=\mu_{0} S_{0} e^{-a \tau_{z}}
$$

The diffuse irradiance $F_{z \downarrow}$ at elevation $z$ is obtained from an empirical formulation [43]. $M_{0}$ and $M_{z}$ are empirical factors representing the unabsorbed fluxes at reference elevation $z_{0}$ and elevation $z$ :

$$
\begin{gathered}
F_{z \downarrow}=F_{\mathrm{z}_{0} \downarrow} \frac{M_{z}-e^{-\tau_{z} / \mu_{0}}}{M_{0}-e^{-\tau_{0} / \mu_{0}}} \\
M_{z}=\left(1-0.027 e^{2 P_{z} / P_{0}}\right)\left[1.075-0.105 \ln \left(1 / \mu_{0}\right)\right]
\end{gathered}
$$


Figure $6 \mathrm{c}$ and $\mathrm{d}$ show the elevation corrected and topographically corrected incoming solar radiation. We then adjust the topographically corrected diffuse and beam components for vegetation using separate transmissivity values for beam and diffuse irradiance $[29,50]$ to obtain vegetation-corrected values. Figure 6 e shows the vegetation corrected values. Reflected radiation depends on the broadband surface albedo $\alpha$ derived from the MODSCAG-estimated grain size [51]. Spatially varying albedo (Figure 6f) is used to calculate the reflected radiation (Figure $6 \mathrm{~g}$ ) and the net solar radiation $Q_{n s}$ (Figure 6h).

\subsection{Longwave radiation}

Net longwave radiation $Q_{n l}$ is comprised of incoming radiation from the atmosphere $L_{A \downarrow}$, incoming radiation from the surrounding terrain $L_{T \downarrow}$, and outgoing radiation from the surface $L_{S \uparrow}$ :

$$
Q_{n l}=L_{A \downarrow}+L_{T \downarrow}-L_{S \uparrow}
$$

$L_{A \downarrow}$ is modeled as a gray body with an effective atmospheric emissivity $\varepsilon_{A}$ and air temperature $T_{A}[52]$ :

$$
L_{A \downarrow}=\varepsilon_{A} \sigma T_{A}^{4}
$$

Using $L_{A \downarrow}$ (Figure 7a) along with $T_{A}$ from NLDAS2, we estimate $\varepsilon_{A}$ for each $1 / 8^{\circ}$ grid cell (Figure $7 \mathrm{~b}$ ). $\varepsilon_{A}$ is spatially integrated using a Gaussian moving average filter to account for time-integrated estimates of $\varepsilon_{A}$ (Figure 7c). Next, $L_{A \downarrow}$ at 100 m (Figure $7 \mathrm{~d}$ ) is estimated using equation (12), and the $100 \mathrm{~m}$ downscaled $T_{A}$, assuming $\varepsilon_{A}$ is constant over each $1 / 8^{\circ}$ grid cell [12].

Slopes are accounted for using parameters developed for mountainous terrain: the sky view factor $V_{d}$ and the terrain configuration factor $C_{t}=1-V_{d}$. The snow emissivity, $\varepsilon_{S}$ is set at 0.99 [53] and $T_{S}$ is the surface temperature of the snow. $L_{A \downarrow}$ in Figure $7 \mathrm{e}$ and $L_{T \downarrow}$ are: 


$$
L_{A \downarrow}+L_{T \downarrow}=\left(\varepsilon_{A} T_{A}^{4}\right) V_{d}+\left(\varepsilon_{S} T_{S}^{4}\right) C_{t}
$$

In the forest, longwave radiation is corrected for vegetation using canopy transmissivity, emissivity and air temperature [29]. Figure $7 f$ shows longwave radiation corrected for vegetation.

Outgoing radiation for snow $L_{S \uparrow}$ (Figure $7 \mathrm{~g}$ ) is the sum of emitted longwave plus the very small fraction that is reflected from the snow surface. The model does not keep track of the internal energy balance of the snowpack, so $T_{S}$ needed for both $L_{T \downarrow}$ and $L_{S \uparrow}$ has to be estimated. The minimum of $0^{\circ} \mathrm{C}$ and $T_{A}$ is used for each hour. Others have found dewpoint temperature can be more accurate, [54] but we found that these temperatures when calculated with NLDAS2 specific humidity were too cold and produced little melt. Effective atmospheric temperatures that could be used in place of $T_{A}$ are not available from NLDAS2. Figure $7 \mathrm{~h}$ shows the final estimate of net longwave radiation $\left(L_{A \downarrow}+L_{T \downarrow}-L_{S \uparrow}\right)$.

\section{Validation of energy balance components}

We validate the downscaled hourly NLDAS2 modeled incoming solar radiation, incoming longwave radiation and air temperature with ground observations. We also compare outgoing longwave radiation with a finer spatial resolution model that calculates the full energy balance [55]. The final energy balance component, reflected solar radiation, is not evaluated, because it is rarely measured over snow, and at the few sites it is measured in the Sierra Nevada, comparison with the satellite estimate is problematic. At a site in the San Juan Mountains of Colorado, where the measurement site itself well represents the surrounding terrain, the MODSCAG snow albedo had an error of $4.2 \%$ when compared to in-situ measurements [25]. More recent work, at the Mammoth Mountain snow study site [34] shows that the mean difference is $10 \%$, very similar to the $-12 \%$ bias adjustment used in this study. Previous 
discussion in section 3.2 addresses errors and adjustments to albedo that would affect the reflected radiation component.

\subsection{Incoming solar}

The CDEC network [2] has a good distribution of sensors co-located with snow pillows. CADWR uses LiCor LI200SZ sensors that have a $\pm 2 \%$ drift over one year and an RMS error of 5\% when compared to more expensive, higherprecision Eppley PSP instruments. 41 sensors (Table 3) totaling 200 stationyears of data (i.e. the average number of years of observations was about 5) were used after being filtered for noise and removing years that were not well calibrated. Hourly data were interpolated when sufficient data were available and a mean was calculated for those days.

Incoming solar radiation is generally measured in flat, unshaded locations. Therefore we compare the observed daily incoming solar radiation to the sum $F_{z \downarrow}+B_{z \downarrow}$, the spatially integrated and elevation adjusted NLDAS2 values. Figure 8a shows the comparison of the modeled and observed incoming solar radiation; the color bar indicates the density of points in each location. Across all stations, the model RMSE is $46 \mathrm{~W} / \mathrm{m}^{2}$, with mean difference of $5 \mathrm{~W} / \mathrm{m}^{2},(1.3 \mathrm{~mm}$ of melt per day). Table 3 shows the statistics for each station; RMSE ranges from 32 to $79 \mathrm{~W} / \mathrm{m}^{2}$, with mean differences between -41 and $+65 \mathrm{~W} / \mathrm{m}^{2}$ across all stations.

Figure $8 \mathrm{~b}$ shows the RMSE listed in Table 3 for each location plotted against elevation. The RMSE increases with elevation in a nearly linear way with elevation, except for two outliers that have values greater than $75 \mathrm{~W} / \mathrm{m}^{2}$. Further inspection of those two stations show they appear to be well calibrated, but one (rkc) had frequent dropouts in the mid-morning and mid-afternoon indicating possible shading from nearby canopy. The other (rav) was located in a valley at $1614 \mathrm{~m}$ with peaks on the west and east sides over $2300 \mathrm{~m}$ so is possibly influenced by topography. The model overestimated incoming solar radiation relative to these two stations (Figure 8c) supporting shadowing of the 
stations as the explanation. While there is an increasing RMSE with elevation, Figure 8c shows that the median difference with elevation has no bias with elevation. A lack of bias with elevation helps ensure that the reconstruction model does not systematically over- or underestimate SWE at different elevations.

\subsection{Incoming longwave}

Incoming longwave radiation is measured in fewer locations, is more difficult to measure well, and remains a challenge in mountainous terrain [57]. We compare NLDAS2 data against measurements from two stations. Incoming longwave radiation at the United States Coast Guard Pier in Tahoe City, CA is measured with a Kipp \& Zonen Net Radiometer, CRN1. It has two CG3

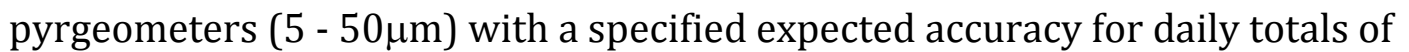
$10 \%$. A second sensor in the same location is an Eppley Precision Infrared Radiometer ( 3.5 to $50 \mu \mathrm{m}$ ) which if well calibrated can measure to within 4 $\mathrm{W} / \mathrm{m}^{2}$ for daily observations [59]. Data at the second station were obtained from the Western Regional Climate Center in Reno, who used a Kipp \& Zonen CGR 3 to measure incoming longwave radiation. Though the Reno station was outside the study area, it was within the modeling domain. Table 4 shows the locations and elevations of the two stations. Figure 9 shows a comparison of the observed and modeled data. NLDAS2 tends to underestimate incoming longwave radiation for both locations, though less so at the higher elevation site; the mean difference for all three measurements was $-30 \mathrm{~W} / \mathrm{m}^{2}$ (7.8 mm/day) with a RMSE of 38 $\mathrm{W} / \mathrm{m}^{2}$. Table 4 shows the error statistics for each station.

\subsection{Outgoing longwave}

To evaluate how the assumption $T_{S}=\min \left(0^{\circ} \mathrm{C}, T_{A}\right)$ (described in Section 3.5) might lead to errors in the energy balance, we utilize estimates from a distributed coupled energy mass-balance model, ISNOBAL [50] because it estimates the snow surface temperature as part of balance the energy equations. 
We used the two different estimates of $T_{S}$ for March $1^{\text {st }}$ to July $1^{\text {st }}$ to calculate the outgoing radiation for snow $L_{S \uparrow}$. The RMSE, median and mean differences between the two methods of estimating outgoing longwave radiation were 4.2 $\mathrm{W} / \mathrm{m}^{2}, 8.1 \mathrm{~W} / \mathrm{m}^{2}$, and $10.4 \mathrm{~W} / \mathrm{m}^{2}$ (2.6 mm/day). The larger mean differences indicate some bigger errors, and visual inspection showed that these errors occurred at the highest elevations. However, error decreased as the melt season progressed from values near $35 \mathrm{~W} / \mathrm{m}^{2}$ early in the year to $0 \mathrm{~W} / \mathrm{m}^{2}$ in mid-May when the snow becomes isothermal nearly everywhere (Figure 10a).

Without modeling the full energy balance, the assumption of $T_{S}$ as the minimum of $0^{\circ} \mathrm{C}$ and $T_{A}$ seems to work relatively well. Another alternative, MODIS-derived land-surface temperature [60], could inform snow surface temperatures in canopy free areas. However, in forested areas the product is difficult to use at its $1 \mathrm{~km}$ resolution because each pixel contains both snow and trees.

\subsection{Air temperature}

Downscaled air temperatures were evaluated with 35 of the 41 sites used for evaluating solar radiation Table 3. The scatter-density plot in Figure 10b shows the modeled and observed air temperatures. The point density is highest at $10^{\circ} \mathrm{C}$ indicating the average air temperature over the entire study area for January $1^{\text {st }}$ to September $30^{\text {th }}$. Table 3 shows the errors at each station. The mean RMSE for all stations is $2.1^{\circ} \mathrm{C}$ with a range of $1.3^{\circ} \mathrm{C}$ to $3.7^{\circ} \mathrm{C}$. The mean difference for all stations is $-0.2^{\circ} \mathrm{C}$ with a range of $-2.4^{\circ} \mathrm{C}$ to $+2.3^{\circ} \mathrm{C}$. For a degree-day factor of $1.5 \mathrm{~mm} \mathrm{deg}^{-1} \mathrm{day}^{-1}$, the range of differences translates to $-3.6 \mathrm{~mm} /$ day and +3.4 $\mathrm{mm} /$ day.

\section{Evaluation of maximum snow water equivalent}

The California Department of Water Resources coordinates more than 50 state, national and private agencies to form the California Cooperative Snow 
Survey. The snow courses in this program are generally located in small, flat clearings, and they provide data we use to statistically evaluate the model throughout the Sierra Nevada (Figure 1). Identifying the exact pixels in our $100 \mathrm{~m}$ grid in which a snow course traverses over a $\sim 300 \mathrm{~m}$ transect with $\sim 10$ observations can be difficult. The MODSCAG $f_{S C A}$ product is at $500 \mathrm{~m}$ resolution at nadir and significantly larger at off-nadir view. Therefore topographic variability within the pixel contributes to the error as well. Finally, the $100 \mathrm{~m}$ pixels may contain forest while the snow courses and snow pillows are in clearings. Therefore, we use pixels within a $3 \times 3$ cell window of the reported location of the snow course. To address the locational error, statistics are calculated for the mean and "best" cell following previous remote sensing studies [61].

If the model performs well at snow pillows and snow courses, it has some degree of validation for the flat areas, with the difference lying mainly in geometry that topographic calculations in the reconstruction model address. To verify model performance on slopes, we performed snow surveys in 2010 at 10 locations.

\subsection{Snow courses}

Members of the California Cooperative Snow Survey measure snow water equivalent near the first of each month in February, March, and April, and in wet years around May $1^{\text {st }}$ too. For each year for each course, the maximum value is compared to the reconstructed value on that date. Over the 12-year period there were 2645 such snow course observations, an average of 220 per year.

Figure 11a shows the snow course SWE plotted against the best of the $3 \times 3$ grid of modeled SWE values. The clustering of values along the 1:1 line show that the model performs well. The histograms in Figure 11b show that the differences between the modeled and observed values are approximately normal throughout the range of wet to dry, with no bias. The snow course 
measurements at monthly intervals do not likely occur at the maximum accumulated SWE, but reconstruction can be carried out from any date after the maximum.

The following discussion about Table 5 uses the "best" error from the $3 \times 3$ grid cell around the snow course. The mean and median values for all years were calculated using the values from each year, because the numbers of observations for each year were nearly identical. Comparisons with seasonal-maximum snow course SWE over all years show an RMSE of $230 \mathrm{~mm}$ with a range of 162 to 315 $\mathrm{mm}$ (Table 5). The mean difference over all years is $72 \mathrm{~mm}$ with a range of -61 to $+171 \mathrm{~mm}$. Raleigh et al [25] provide likely sources of positive bias, here the overestimates are possibly from 1) overestimating snow cover fraction under forest canopy, 2) not accounting for ephemeral snow 3) false positives for fractional snow cover in the summer when melt is highest. The model performs very well in the wettest years; for example 2005, 2006 and 2011 have mean differences of $+27 \mathrm{~mm},+72 \mathrm{~mm}$ and $+23 \mathrm{~mm}$. The model over-predicts in the driest years, for example 2001 and 2007 have mean differences of $+164 \mathrm{~mm}$ and $+135 \mathrm{~mm}$. The largest errors are seen in 2000, when snow accumulation was near the mean and snow cover data from a similar year was used for March because MODIS had not yet been launched; however the model performs well in other near-average years.

Recent modeling using the reconstruction method in the Tuolumne and Merced River basins provides an opportunity for comparison. Rice et al. [15] reconstructed SWE using a degree-day method calibrated separately for 2004 and 2005 using temperature data from nine stations within the basins. They report mean absolute errors (MAE) of $130 \mathrm{~mm}$ and $210 \mathrm{~mm}$ for 2004 and 2005. The combined energy balance-degree day reconstruction model described here had smaller MAE, indicating better performance than the degree-day model specifically calibrated to the Tuolumne and Merced River basins in those two 
years. This superior performance of models that include energy balance is also demonstrated in another recent study [63].

\subsection{Errors related to elevation and latitude}

It is important to understand how the model performs through the range of latitudes and elevations to gain confidence in the analysis of the distribution of SWE at maximum accumulation in section 6. Of particular interest are systematic under- or overestimates at particular latitudes or elevations.

Table 6 shows the errors summarized by $0.5^{\circ}$ increments of latitude and 250 $m$ increments of elevation. With respect to latitude, the mean difference is positive in the North and Central Sierra Nevada reaching $173 \mathrm{~mm}$ at $40.5^{\circ} \mathrm{N}$ but smaller south of $38^{\circ} \mathrm{N}$ with a mean difference of $12 \mathrm{~mm}$ at $36.0^{\circ} \mathrm{N}$. The median differences follow the same trend but are smaller in magnitude indicating a few large errors. With respect to elevation, there is no clear trend. The magnitude of the errors by elevation or latitude are too small to significantly change the trends described in section 6.

\subsection{0 snow surveys}

We conducted field snow surveys in 2010 in the mountains west of Lake Tahoe to provide ground-based estimates of SWE in $500 \times 500 \mathrm{~m}^{2}$ grid cells. Thus, each survey covered 25 model cells of $100 \mathrm{~m}$. Snow density was measured in 10 $\mathrm{cm}$ increments from the snow surface to the ground in the center of each $500 \times 500 \mathrm{~m}^{2}$ grid cell using a $1000 \mathrm{~mL}$ RIP1 cutter, manufactured by Snowmetrics. Using probes, depths were measured along transects in the cardinal directions at $25 \mathrm{~m}$ intervals from the center of the snow pit to the edge of the grid element. In the melt season density varies much less than depth [64] so we sampled when melt had just begun after peak SWE in the period from April 17 to May 3. Combining the depth and density information yields an estimate of SWE that can be used to validate the retrospective model. We 
selected field sites where reconstructed SWE differed significantly from SWE interpolated from snow pillows. Each of the sites chosen had a northern or southern aspect to highlight variable solar radiation and was nearly homogenous in slope and aspect and forest cover $(<15 \%)$ to enable the best comparison between satellite and in-situ measurements. The sites all had a slope of about $20^{\circ}$, enough to affect solar geometry but not so steep as to incur avalanche risk during sampling. Sites were near enough to a road or ski area to enable sampling without an overnight stay in the backcountry. The criteria resulted in seven study areas spanning the American River basin from Castle Peak in the north to Covered Wagon Peak in the south. In the seven study areas we sampled 10 grids in the 2010 water year between April $17^{\text {th }}$ and May $3^{\text {rd }}$ (Table 7). Elevation and accumulated solar radiation have previously been identified as viable predictors of SWE variability $[32,65]$. The accumulated solar radiation was summed for January $1^{\text {st }}$ to the date of the survey (Table 7). Measured snow depth was regressed against elevation (from GPS coordinates), accumulated solar radiation, and the mean value for the set of measurements for each of the 25 modeled $100 \mathrm{~m}$ grid cells. The regression relationship for each survey was used along with a $30 \mathrm{~m}$ digital elevation model (combined SRTM/NED) and the accumulated solar radiation to predict the depth for every $30 \mathrm{~m}$ grid cell within the survey area. With these predicted estimates of depths and density data from the snow pits, the SWE was calculated for the $27530 \mathrm{~m}$ grid cells contained in each $500 \mathrm{~m}$ surveyed cell using the following equation. Subscripts for each pixel are removed for clarity:

$$
S W E=\int_{0}^{d} \rho_{s}(z) d z=\sum_{0}^{n} \rho_{s} \Delta d_{n}
$$

$\rho_{S}$ is the density of snow, $z$ is the depth of each measurement, $d$ is the total depth, $n$ is the number of layers, and $\Delta d_{n}$ is the thickness of each layer $(10 \mathrm{~cm})$. When snow depth was greater than the depth of the snow pit, the density from 
the pit measurement at the deepest layer was used. This measurement is called the "predicted SWE" in Table 7, which also shows the reconstructed SWE.

The mean difference when comparing the mean of the $25100 \mathrm{~m}$ surveyed pixels is $106 \mathrm{~mm}$, consistent with results obtained in the snow pillow and snow course comparisons. The $R^{2}$ value comparing predicted with reconstructed SWE is 0.82 . These results confirm good model performance for slopes up to $20^{\circ}$, which comprise $78 \%$ of the area in the HUC8 basins examined in this study. Having gained confidence in the ability of the model to estimate SWE at maximum accumulation, we analyze the reconstructed SWE in section 6.

\subsection{Evaluation of errors}

Theoretically, errors in SWE from the reconstruction are smallest late in the season and as the model runs back to peak SWE the error compiles over time from both inputs in snow cover and energy balance components. However, Raleigh et al [14] suggest that in areas with high precipitation uncertainty, such as mountainous regions, the reconstruction provides better estimates of SWE than other methods.

Recent work that explores incoming shortwave and longwave radiation analyzing both the biases and random noise on SWE maritime snowpack are more sensitive to radiation errors than in other climates [66]. We see this manifested as errors in incoming longwave radiation, as detailed in Section 4 where we compared each component of the energy balance except for reflected (outgoing) solar radiation. The largest errors come from incoming longwave ($30 \mathrm{~W} / \mathrm{m}^{2}$ ), but half of this error is balanced by the positive biases from incoming solar radiation $\left(5 \mathrm{~W} / \mathrm{m}^{2}\right)$ and outgoing longwave radiation $\left(10.4 \mathrm{~W} / \mathrm{m}^{2}\right)$. In Section 5 we estimated the errors in maximum snow water equivalent and find positive biases that are counterintuitive to the negative bias from incoming longwave. The two possible remaining components are 1) reflected (outgoing) solar radiation or 2) errors from snow cover. 
Though the albedo used in this study performs better than models based on snow age, it may have a small bias (too dark) that could explain the positive biases in SWE. An alternative explanation is a positive bias in snow cover because clouds are not always properly discriminated from snow. An overestimate in snow cover would lead to an overestimate in melt especially if the clouds occur late in the season when melt is high. Similarly, maximum SWE can be overestimated if snowfall occurs late in the season after maximum SWE. This extends the snow cover record so melt is calculated over too many days. Other studies have estimated this late snowfall for example as 7\% of total SWE in the Upper Rio Grande [12] and in the Sierra Nevada average about 9\% of total SWE [67].

In the following section we analyze the distribution of SWE reconstructed to the maximum SWE date with latitude and elevation for regions and basins in the Sierra Nevada. On average this SWE is $70 \mathrm{~mm}$ more than SWE reconstructed to April 1.

\section{Distribution of snow water equivalent}

In this section, the relationship of SWE at maximum accumulation with elevation and latitude is explored for the Sierra Nevada as a whole. Next, the relationship of SWE at maximum accumulation with elevation is explored for the Sacramento, San Joaquin, Tulare and Lahontan drainages, followed by the 18 HUC8 basins within them (Figure 1). Finally, the relationship of SCA and SWE at maximum accumulation is examined. For the analyses in sections 6.1, 6.2 and 6.3, we use the SWE at maximum accumulation for each pixel (section 3.1), while for Section 6.4 we use the SWE reconstructed to each calendar date in order to match the snow covered area observations. In Section 6, we refer to SWE at maximum accumulation as simply, SWE. 


\subsection{Whole Sierra Nevada}

\subsubsection{Elevation}

The mean SWE in 100 m elevation bands (independent of latitude) for each of the 12 years that vary from dry to wet was calculated to examine the relationship of SWE with elevation. Figure 12a shows that SWE increases in a linear trend with elevation and then decreases above a threshold elevation (Table 1). The steepest slopes at the highest elevations do not hold snow well, wind redistribution is more prevalent there, and an orographic effect levels off as the mountain barrier gives way to lower elevations on the leeward side of the ridge. Orographic [68] and atmospheric moisture [69] has been studied in the Sierra Nevada, so we focus specifically on the model results herein.

The reconstructed SWE shows that wet years, like 2011 and 2006, show a greater increase of SWE with elevation than dry years, like 2007, because in wet years storms continue through April and May when the snowline is higher. The largest deviation from the linear trend is at $1900 \mathrm{~m}$ the elevation at which Lake Tahoe lies. This elevation band is highly influenced by Lake Tahoe that does not freeze in the winter.

Figure 12b shows how SWE values for each year differ from the mean for all years with respect to elevation. There is less variability at lower elevations because these elevations generally have less snow. In 2003 (orange) and 2005 (light blue) colder temperatures at $1500 \mathrm{~m}$ result in snowier winters at these low elevations and significant SWE anomalies. Figure 12c shows the total SWE volume summed for each elevation and the inset shows the distribution of area with elevation. Moderate and lower elevations are important, because they cover a large area. The maximum volume for 11 of 12 years occurs near $2200 \mathrm{~m}, 400 \mathrm{~m}$ above the mean elevation (black line) for the Sierra Nevada.

Figure $12 \mathrm{~d}$ shows how SWE volumes for each year differ from the mean SWE volume for all years with respect to elevation. The variability of SWE volume is 
largest for elevations between $1500 \mathrm{~m}$ and $3000 \mathrm{~m}$. The anomalies in SWE from 2003 and 2005 contribute significant volumes because of the large area at 1500 $\mathrm{m}$ while in 2006 late season snow accumulates between $2500 \mathrm{~m}$ and $3000 \mathrm{~m}$. 2001, a dry year, had a wet winter and dry spring leading to average SWE volumes at low elevations. In contrast, 2000 , a mean year, had a dry winter and wet spring leading to dry conditions at low elevations.

In summary, the differences in weather patterns and the distribution of area with elevation combine to shape the SWE depth and volume distributions.

\subsubsection{Latitude}

Figure 13a shows mean SWE in $0.5^{\circ}$ increments of latitude for each of the 12 years. SWE increases with latitude in both wet and dry years when all latitudes are considered, but north of $37^{\circ}$ in wet years this pattern is less evident. Positive anomalies correspond to high elevation bands at those latitudes, particularly evident for the Kings River basin between $37^{\circ}$ and $37.5^{\circ} \mathrm{N}$. A negative anomaly at $38^{\circ}$ corresponds to a large valley in the Crowley Lake basin, and one at $39^{\circ}$ corresponds to Lake Tahoe.

Figure 13b shows how SWE values for each year differ from the mean SWE for all years with respect to latitude. Variability is smallest in the south where SWE depth is the smallest and increases moving northward until $38^{\circ}$ where it stabilizes. At latitudes north of $38.5^{\circ}$, the absolute difference from normal is greater for wet years than dry.

Figure $13 \mathrm{c}$ shows the total SWE volumes for latitude bands from $35^{\circ}$ to $41^{\circ}$. The effect from Lake Tahoe is seen as a large dip at $39^{\circ}$. The SWE volume differences in Figure 13d are similar to those of SWE in Figure 13b but larger north of $37.5^{\circ}$ where the area balances slightly lower contributions from SWE expressed as a depth. 


\subsection{Sacramento, San Joaquin, Tulare and Lahontan}

Section 6.1 explores the relationship of SWE with elevation and latitude for the entire Sierra Nevada. However, regional differences, which cannot be explained by looking at the Sierra Nevada as a whole, are explored here for the 4 drainages. Figure 14 repeats the analysis shown in Figure 12 for the four drainages shown in Figure 1.

\subsubsection{SWE depth and threshold elevation}

In the Sacramento drainage, SWE (Figure 14a) increases linearly with elevation to $3100 \mathrm{~m}$ followed by a small decrease. The rate of increase of SWE with elevation is larger than the Sierra Nevada as a whole (Figure 12a) possibly from the Sierra Barrier Jet [68] that is blocked by the Southern Sierra and channeled northward. With these storms that can be more frequent in the Northern Sierra Nevada, the Sacramento drainage does not reach a threshold elevation. Possible explanations include that relative to the rest of the Sierra Nevada there are lower wind speeds, denser snow with warmer temperatures, more vegetation, and less rugged topography.

In the San Joaquin drainage, SWE (Figure 14e) increases linearly with elevation from $800 \mathrm{~m}$ to about $2500 \mathrm{~m}$ in wet years. For elevations above 2500 $\mathrm{m}, \mathrm{SWE}$ increases with elevation but at a reduced rate to the threshold elevation at $3700 \mathrm{~m}$. For mean or dry years the initial increase from $800 \mathrm{~m}$ to $2500 \mathrm{~m}$ is at a lower rate than wet years. SWE drastically decreases above the threshold elevation.

In the Tulare drainage, SWE (Figure 14i) increases linearly from $800 \mathrm{~m}$ to the threshold elevation at $3700 \mathrm{~m}$. The variability of SWE with elevation for wet and dry years is smaller than for the San Joaquin at elevations below $3000 \mathrm{~m}$.

In the Lahontan drainage, SWE (Figure 14m) increases linearly from $1500 \mathrm{~m}$ to $3000 \mathrm{~m}$. From $3000 \mathrm{~m}$ to the threshold elevation at $3500 \mathrm{~m}$, SWE values are constant, similar to the plateau seen in the San Joaquin. Above the threshold 
elevation at $3500 \mathrm{~m}$, SWE decreases but not as drastically as for the San Joaquin and Tulare drainages. The increase in SWE from $3900 \mathrm{~m}$ to $4000 \mathrm{~m}$ can be attributed to the Crowley River basin, described later in section 6.3.

Figure 14, column 2 shows how SWE values for each year differ from the mean for all years with respect to elevation. SWE values in the San Joaquin, Tulare and Lahontan drainages have similar patterns of differences from the mean with small values at low elevations, large values for moderate elevations, and smaller values at the highest elevations. SWE differences from the mean are less pronounced in the Tulare drainage at lower elevations than in the San Joaquin or Lahontan drainages. SWE differences in the Lahontan are less dependent on elevation while in the Sacramento there are increasingly larger differences with elevation (Figure 14b) reaching up to $\pm 800 \mathrm{~mm}$ SWE at $3200 \mathrm{~m}$. For all four drainages the greatest differences of SWE from the mean occur at the or near the threshold elevation.

\subsubsection{SWE Volume}

In the Sacramento and San Joaquin, the largest SWE volumes (Figure 16c\&g) are at 1800 and $2500 \mathrm{~m}$, respectively, a few hundred meters higher than the mean elevation for each region. SWE volumes in the Tulare (Figure 14k) are bimodal in the wet years at $2700 \mathrm{~m}$ and $3400 \mathrm{~m}$, but nearly constant in the dry years. The bimodal or constant SWE volumes can be attributed to the fact that the Kings and Kern each have 2 forks that follow different accumulation patterns (see section 6.3 and Figure 15g). SWE volumes in the Lahontan (Figure 14o) are largest at $2500 \mathrm{~m}$ near the mean elevation for the region, in contrast to the basins that face west.

The largest absolute differences from the mean SWE volumes are in the Sacramento (Figure 14d), but the ones in the San Joaquin (Figure 14h) are similar in total volume because of the larger elevation range in which the differences occur. The more arid Tulare and Lahontan (Figure 14i and $\mathrm{p}$ ) have 
moderate volume anomalies. The large volume anomalies seen in the Sierra Nevada in 2003 (orange) and 2005 (light blue) described in section 6.1.2 and shown in Figure 12d can be attributed almost solely to contributions from the Sacramento (Figure 14d) where the lower elevations and higher latitudes have a larger effect on the snow line. In 2006, when average temperatures were $7^{\circ}$ warmer in the Sacramento than in 2003, the San Joaquin, Tulare, and Lahontan contributed larger total volumes of SWE.

In summary, the SWE and SWE volumes help explain the patterns seen in the Sierra Nevada as a whole. In different drainages, the distributions of elevation and area combine to produce different patterns of total volume from year to year. Some of the patterns may be better understood through analyses of the individual patterns in the basins that make up each region.

\subsection{Basins}

In this section the relationship of SWE with elevation for basins within each of the four drainages is explored. The mean SWE for the 12-year period in each basin is used for the analysis (Figure 15) in contrast to sections 6.1 and 6.2 where we show all 12 years. In the North, SWE increases by $900 \mathrm{~mm}$ for every $\mathrm{km}$ of elevation $(900 \mathrm{~mm} / \mathrm{km})$. Moving southward, in general the rate decreases all the way to the Kern River basin where SWE increases by $300 \mathrm{~mm}$ for every $\mathrm{km}$ of elevation. This parameter is often used in hydrologic modeling to distribute precipitation from station data..

Rates of increase in SWE with elevation are similar $(900 \mathrm{~mm} / \mathrm{km}$ to $700 \mathrm{~mm} / \mathrm{km}$ ) for the three basins within the Sacramento region (Figure 15a) and the three most northern basins in the San Joaquin region (Figure 15b). In the Feather an inflection in the rate of increase in SWE at $2400 \mathrm{~m}$ is caused by an orographic effect attributed to Mt. Lassen. The Feather reaches a threshold elevation at $2900 \mathrm{~m}$, while the American, Yuba, Cosumnes, Mokelumne, and Stanislaus do not reach an elevation threshold (Table 1). Starting with the 
Tuolumne $(600 \mathrm{~mm} / \mathrm{km})$, the rate at which SWE increases with elevation progressively decreases moving southward to the Merced, San Joaquin and Kings Basins $(400 \mathrm{~mm} / \mathrm{km})$ and elevation thresholds appear in all the basins. SWE values in the Tuolumne and San Joaquin basins reach a plateau at $2500 \mathrm{~m}$ and $3000 \mathrm{~m}$, respectively, corresponding to the plateau seen in the San Joaquin region (Figure 14e). The threshold elevations for the Tuolumne, Merced, and San Joaquin basins are near $3700 \mathrm{~m}$.

In the Kern, which flows southward bounded by crest of the Sierra Nevada on the East and the Great Western Divide on the West, SWE increases with elevation at a rate of $300 \mathrm{~mm} / \mathrm{km}$ from $1200 \mathrm{~m}$ to $3000 \mathrm{~m}$ before more than tripling to $1000 \mathrm{~mm} / \mathrm{km}$ from $3000 \mathrm{~m}$ to $3750 \mathrm{~m}$ (the threshold elevation), a rate only surpassed in the Feather River basin. SWE in the Upper Tule and Kaweah (Figure 15c) have a hybrid-like behavior of the Kings and Kern. The Tulare region's threshold elevation seen in Figure 14i better matches the Kern and Kings whose influence dominates due to the large area relative to the Kaweah and Tule.

On the eastern side of the Sierra in the Lahontan, SWE increases at a rate just under $700 \mathrm{~mm} / \mathrm{km}$ in the Carson, West Walker, East Walker, and Crowley River basins before reaching threshold elevations at $3000 \mathrm{~m}, 3100 \mathrm{~m}, 3200 \mathrm{~m}$, and $3600 \mathrm{~m}$, respectively (Table 1). These progressive threshold elevations combine to cause the plateaued SWE in the Lahontan drainage, seen in Figure $14 \mathrm{~m}$. The Crowley Lake basin is located east of the San Joaquin River basin with a natural gap in the Sierra Nevada, where moisture is not blocked or precipitated out by higher elevations. This explains the increase in SWE above $3900 \mathrm{~m}$ in the Lahontan region (Figure 14m) and the reason why the Mammoth Mountain Ski Area is located at the top of this basin. Lake Tahoe is included in the Truckee River basin because it drains into the Truckee River near Tahoe City. It has a convexly increasing rate of SWE with elevation from $1900 \mathrm{~m}$ (lake level) to its threshold elevation at $2500 \mathrm{~m}$. 


\subsection{Snow-covered area and snow water equivalent}

Figure 16 shows April $1^{\text {st }}$ SWE for the American and Kern River basins in 2007 and 2011. In the American, the dry (2007) and wet years (2011) differ little in total snow covered area (SCA), but in the Kern there is substantially more SCA in 2011 than there was in 2007. For river basins that show a range of SCA between wet and dry years best exemplified by the Kern, the relationship between SCA and SWE has the potential to help estimate SWE from real time observations of SCA. In fact prior research has shown that even in the American River basin depletion curves can be derived from maximum SWE [71].

We calculate the SCA and SWE volume in each river basin for each year from March $1^{\text {st }}$ to August $1^{\text {st }}$. Figure 17 shows the SCA and SWE volumes on April $1^{\text {st }}$ (top) and June $1^{\text {st }}$ (bottom) grouped by drainage. 12 points are plotted for each basin, one for every year. On April $1^{\text {st }}$ in basins such as the Feather, there is a large range of both SCA and SWE, while in other basins such as the Yuba, the range of SCA is small compared to a larger range in SWE. The Yuba has a SWE volume range of $1.5 \mathrm{~km}^{3}$ and SCA range of $500 \mathrm{~km}^{2}$ on April $1^{\text {st }}$, while the Feather has a SWE volume range of $4.5 \mathrm{~km}^{3}$ (3× Yuba) and a SCA range of 5000 $\mathrm{km}^{2}\left(10 \times\right.$ Yuba). Two months later in the melt season, on June $1^{\text {st }}$, the range of SCA for the Yuba doubles and SCA becomes a better predictor of SWE for the Yuba as well as other basins.

To test the relationship of SCA and SWE through time, the $R^{2}$ statistic is calculated from March $1^{\text {st }}$ to July $1^{\text {st }}$ for each basin using the 12 years of data. Figure 18 shows the $R^{2}$ statistic consistently increases in value from March $1^{\text {st }}$ to July $1^{\text {st }}$ in each of the four drainages. Moving from March $1^{\text {st }}$ to April $1^{\text {st }}$, the error related to accumulated melt lowers and at lower elevations, SWE will likely have reached its maximum. The rise in elevation of the snow free area becomes a measure of the SWE depth with elevation as SCA will decrease more rapidly in drier years than in mean years because of the proportionally smaller SWE with 
increasing elevation. For wet years, if snow is still falling late in the season at moderate to high elevation, the snow line may remain stable.

In the month of April, some complicated dynamics result in constant or decreasing $R^{2}$ values. In wet years or years with late SWE accumulation, basins are still accumulating snow, possibly more so at the higher elevations while SCA may remain relatively unchanged if storms are warm or alternatively could increase if storms are cold. In dry years or years with early SWE accumulation, the snow line is likely moving up in elevation but may have reached a critical SWE where the SCA is not changing drastically. The relatively constant $R^{2}$ values in the lowest and highest elevation drainages support this hypothesis. In the lower elevation Sacramento region, SCA is mainly decreasing and new storms are likely to add snow to only the highest elevations. In the Lahontan because of the high elevations, temperatures are colder and most basins are likely to receive snow in storms, keeping the relationship from early in the season intact. Basins in the San Joaquin and Tulare drainages have the largest elevation ranges (Table 1) and complicated dynamics between SWE and SCA.

In May the number of storms contributing substantial SCA or SWE is significantly less than earlier months, and as temperatures warm, the complicated dynamics turn to simpler melt dynamics allowing SCA to become a stronger measure of SWE than previously. After June $1^{\text {st }}$ the storms contribute little to SWE or SCA, and melt progresses to the highest elevations where SWE differs the most among years (Figure 14, column 2). SCA becomes an almost perfect predictor of remaining SWE with $R^{2}$ values near 1 . The lower value in the Sacramento in June can be at least partly attributed to the cloud error visible in Figure 4.

The $R^{2}$ relationship suggests that SCA improves as an indicator of total SWE volume from March through July. For ungauged basins a historical database of SWE from reconstruction along with SCA could be used to predict SWE relative to previous years. Given the similarity of the curves for the 18 basins, the 
relationship between SCA and SWE is robust, regardless of the range of SCA (Figure 16 and Figure 17, x-axis).

\section{Conclusion}

In situ observations of snow do not provide adequate spatial coverage in the Sierra Nevada because they do not sample slopes or the highest elevations. The reconstruction model provides a spatially distributed estimate of maximum snow water equivalent for each pixel independently over the whole range, allowing the calculation of basin-wide water volumes. Estimates of declining SWE after the maximum accumulation are also available, but estimates during the accumulation part of the season are not. Model output from 12 years of data shows the ability to accurately estimate the maximum accumulation at snow pillows and snow courses as well as on slopes, though error analysis shows small overestimate on average. The model uses available satellite-derived inputs that could be used to drive real time models. MODIS data are available worldwide, NLDAS data are available only for the continental US, but a similar product, GLDAS, is available worldwide at twice the spatial resolution. The model relied $\backslash$ on ground data for maximum SWE dates, so SWE differed little from April $1 \mathrm{SWE}$ and thus is applicable to regions without such data, such as the Hindu Kush or Himalaya.

In the Sierra Nevada, the reconstruction model shows that above a threshold elevation, snow accumulation levels off or decreases in the San Joaquin, Tulare and Lahontan drainages while in the Sacramento accumulation increases to the highest elevations except in the Mt. Lassen area. The distribution of SWE with elevation and latitude depends on temperatures and timing of the storms. Between drainages there is a significant difference in the relationship of SWE with elevation and the patterns of anomalies from year to year that likely depend on storm tracks' relation to the basin's orientation. Within drainages, 
accumulations in individual basins can differ substantially or they can be similar. This study has helped to resolve which relationships, such as SWE with elevation, may be transferable between basins.

For river basins in the Sierra Nevada, the relationship of SCA and SWE is fairly robust for determining the relative amount of accumulation, further simplifying our predictive capabilities and demonstrating the possibility for realtime SWE estimates. Furthermore, the relationship of SWE with elevation derived from this study can be used as way for water managers to understand the distribution of SWE at elevations above snow pillows and snow courses.

\section{Acknowledgments}

NASA Cooperative Agreement NNX11AK35A, NASA Fellowship NNX09AN75H, National Geospatial Intelligence Agency Grant N00244-07-1-0013, and USAID Cooperative Agreement No. AID-OAA-A-11-00045 supported this work.

\section{Figure captions}

Figure 1: (a) Sierra Nevada study area and its four major drainages with snow pillows and snow courses; (b) Elevation and HUC8 basins that have full natural flow data. The Feather, Tahoe/Truckee, American, and Kern have multiple forks represented with dotted lines.

Figure 2: Example of unmeasured snow in the Tuolumne and Merced River basins:

(a) Landsat snow-covered area $\left(f_{S C A}\right)$, July $2^{\text {nd }} 2011$; (b) Landsat $f_{S C A}$, July $18^{\text {th }} 2011$; (c) snow pillow observations, with the dates of the images identified. Significant snow still existed after snow from all pillows had disappeared.

Figure 3: Pixel specific dates of maximum accumulation determined from snow courses and snow pillows for the 12-year period.

Figure 4: Reconstruction model output for the driest (2007, top row) and wettest (2011, bottom) years in the 12-year study period on the first of each month from March to July. The black outlines show the Tuolumne and Merced basins, and the insets at the lower left of each image show the details for those basins. 
Figure 5: Snow albedo from MODSCAG: (a) minimum value for each pixel in 20002011 (when snow-covered); (b) mean value for each pixel in 2000-2011; (c) maximum value for each pixel in 2000-2011.

Figure 6: Shortwave radiation in the Tuolumne-Merced River basins for May 24, 2006 noon, all at $100 \mathrm{~m}$ resolution except (a) 1/8 NLDAS2 incoming; (b) incoming spatially integrated; (c) incoming adjusted for elevation; (d) incoming adjusted for topography; (e) incoming adjusted for vegetation; (f) snow albedo; (g) outgoing; (h) net.

Figure 7: Longwave radiation in the Tuolumne-Merced River basins for May 24, 2006 noon, all at $100 \mathrm{~m}$ resolution except (a) and (b). (a) $1 / 8^{\circ}$ NLDAS2; (b) $1 / 8^{\circ} \varepsilon_{A}$ incoming; (c) incoming spatially integrated; (d) incoming adjusted for elevation; (e) incoming adjusted for topography; (f) incoming adjusted for vegetation; (g) outgoing (h) net.

Figure 8: Evaluation of modeled incoming solar to observed solar at 41 stations: (a) scatter plot; (b) RMSE with elevation; (c) mean difference with elevation.

Figure 9: Evaluation of modeled incoming longwave with observed incoming longwave.

Figure 10: (a) Evaluation of outgoing longwave radiation with ISNOBAL snow surface temperatures; (b) Evaluation of modeled air temperature with observed air temperature at 35 stations.

Figure 11: Evaluation of reconstructed SWE using snow courses. (a) scatter plot of modeled and snow course SWE; (b) histograms of modeled and snow course SWE differences. Red to orange colors represent SWE from drier snow years and yellow to blue colors represent SWE from wetter years.

Figure 12: The distribution of SWE with elevation for the Sierra Nevada: (a) mean SWE; (b) difference of yearly SWE from 12-year mean; (c) SWE volume; (d) difference of yearly SWE volumes from 12-year mean.

Figure 13: The distribution of SWE with latitude for the Sierra Nevada: (a) mean SWE; (b) difference of yearly SWE from 12-year mean; (c) SWE volume; (d) difference of yearly SWE volumes from 12-year mean. 
Figure 14: The distribution of SWE with elevation for the Sacramento, San Joaquin, Tulare, and Lahontan. Left to right, the columns are: mean SWE, difference of yearly SWE from 12-year mean, SWE volume, and difference of yearly SWE volume from 12-year mean.

Figure 15: 12 year mean SWE (top) and 12 year mean SWE volume (bottom) for 18 HUC8 River basins separated by drainage.

Figure 16: SWE on April 1 in 2007 and 2011 in the American (left) and Kern (middle and right) River basin.

Figure 17: Relationship of April 1 (top) and June 1 (bottom) SCA and SWE for HUC8 river basins in each of the 4 drainages.

Figure 18: $R^{2}$ statistic for SCA and SWE on March 1st to July 1st for each of the 4 drainages.

\section{References}

[1] NOAA/NWS. California Nevada River Forecast Center. http://www.cnrfc.noaa.gov/. [2] California Department of Water Resources. California Data Exchange Center. http://cdec.water.ca.gov/.

[3] Dozier J. Mountain hydrology, snow color, and the fourth paradigm. Eos Trans Am Geophys Union (2011), 92:373-375. http://dx.doi.org/10.1029/2011E0430001.

[4] Mote PW, Hamlet AF, Clark MP, Lettenmaier DP. Declining mountain snowpack in western North America. Bull Am Meteorol Soc (2005), 86:39-49. http://dx.doi.org/10.1175/bams-86-1-39.

[5] Maurer EP, Stewart IT, Bonfils C, Duffy PB, Cayan D. Detection, attribution, and sensitivity of trends toward earlier streamflow in the Sierra Nevada. J Geophys Res (2007), 112:D11118. http://dx.doi.org/10.1029/2006JD008088.

[6] Milly PCD, Betancourt J, Falkenmark M, Hirsch RM, Kundzewicz ZW, Lettenmaier DP, et al. Stationarity is dead: Whither water management? Science (2008), 319:573-574. http://dx.doi.org/10.1126/science.1151915.

[7] Seager R, Ting MF, Held I, Kushnir Y, Lu J, Vecchi G, et al. Model projections of an imminent transition to a more arid climate in southwestern North America. Science (2007), 316:1181-1184. http://dx.doi.org/10.1126/Science.1139601.

[8] Lettenmaier DP, Alsdorf D, Dozier J, Huffman GJ, Pan M, Wood EF. Inroads of remote sensing into hydrologic science during the WRR era. Water Resour Res (2015), 51:73097342. http://dx.doi.org/10.1002/2015WR017616.

[9] Rollins MG. LANDFIRE: A nationally consistent vegetation, wildland fire, and fuel assessment. Int J Wildland Fire (2009), 18:235-249.

http://dx.doi.org/10.1071/WF08088. 
[10] Martinec J, Rango A. Areal distribution of snow water equivalent evaluated by snow cover monitoring. Water Resour Res (1981), 17:1480-1488.

http://dx.doi.org/10.1029/WR017i005p01480.

[11] Cline DW, Bales RC, Dozier J. Estimating the spatial distribution of snow in mountain basins using remote sensing and energy balance modeling. Water Resour Res (1998), 34:1275-1285. http://dx.doi.org/10.1029/97WR03755.

[12] Molotch NP, Margulis SA. Estimating the distribution of snow water equivalent using remotely sensed snow cover data and a spatially distributed snowmelt model: A multi-resolution, multi-sensor comparison. Adv Water Resour (2008), 31:1503-1514. http://dx.doi.org/10.1016/j.advwatres.2008.07.017.

[13] Molotch NP. Reconstructing snow water equivalent in the Rio Grande headwaters using remotely sensed snow cover data and a spatially distributed snowmelt model. Hydrol Process (2009), 23:1076-1089. http://dx.doi.org/10.1002/hyp.7206. [14] Raleigh MS, Lundquist JD. Comparing and combining SWE estimates from the SNOW-17 model using PRISM and SWE reconstruction. Water Resour Res (2012), 48. http://dx.doi.org/10.1029/2011WR010542.

[15] Rice R, Bales RC, Painter TH, Dozier J. Snow water equivalent along elevation gradients in the Merced and Tuolumne River basins of the Sierra Nevada. Water Resour Res (2011), 47:W08515. http://dx.doi.org/10.1029/2010wr009278.

[16] Dozier J, Bair EH, Davis RE. Estimating the spatial distribution of snow water equivalent in the world's mountains. WIREs Water (2016):in press.

http://dx.doi.org/10.1002/wat2.1140.

[17] Brubaker K, Rango A, Kustas W. Incorporating radiation inputs into the snowmelt runoff model. Hydrol Process (1996), 10:1329-1343.

http://dx.doi.org/10.1002/(SICI)1099-1085(199610)10:10<1329::AIDHYP464>3.0.CO;2-W.

[18] Jepsen SM, Molotch NP, Williams MW, Rittger KE, Sickman JO. Interannual variability of snowmelt in the Sierra Nevada and Rocky Mountains, United States: Examples from two alpine watersheds. Water Resour Res (2012), 48:W02529. http://dx.doi.org/10.1029/2011WR011006.

[19] Winstral A, Marks D, Gurney R. Assessing the sensitivities of a distributed snow model to forcing data resolution. J Hydrometeorol (2014), 15:1366-1383. http://dx.doi.org/10.1175/JHM-D-13-0169.1. [20] U.S. Army Corps of Engineers. Snow Hydrology: Summary Report of the Snow Investigations. Portland, OR: North Pacific Division, Corps of Engineers; 1956.

[21] Rohrer MB, Braun LN. Long-term records of snow cover water equivalent in the Swiss Alps. 2. Simulation. Nord Hydrol (1994), 25:65-78.

http://dx.doi.org/10.2166/nh.1994.004.

[22] Molotch NP, Painter TH, Bales RC, Dozier J. Incorporating remotely-sensed snow albedo into a spatially-distributed snowmelt model. Geophys Res Lett (2004), 31:L03501. http://dx.doi.org/10.1029/2003GL019063.

[23] Flanner M, Zender C. Linking snowpack microphysics and albedo evolution. J Geophys Res (2006), 111:D12208. http://dx.doi.org/10.1029/2005JD006834. [24] Skiles SM, Painter TH, Deems JS, Bryant AC, Landry CC. Dust radiative forcing in snow of the Upper Colorado River Basin: 2. Interannual variability in radiative forcing and snowmelt rates. Water Resour Res (2012), 48:W07522.

http://dx.doi.org/10.1029/2012wr011986. 
[25] Painter TH, Rittger K, McKenzie C, Slaughter P, Davis RE, Dozier J. Retrieval of subpixel snow covered area, grain size, and albedo from MODIS. Remote Sens Environ (2009), 113:868-879. http://dx.doi.org/10.1016/I.Rse.2009.01.001.

[26] Bryant AC, Painter TH, Deems JS, Bender SM. Impact of dust radiative forcing in snow on accuracy of operational runoff prediction in the Upper Colorado River Basin. Geophys Res Lett (2013), 40:3945-3949. http://dx.doi.org/10.1002/grl.50773. [27] Dozier J, Painter TH, Rittger K, Frew JE. Time-space continuity of daily maps of fractional snow cover and albedo from MODIS. Adv Water Resour (2008), 31:1515-1526. http://dx.doi.org/10.1016/j.advwatres.2008.08.011.

[28] Durand M, Molotch NP, Margulis SA. Merging complementary remote sensing datasets in the context of snow water equivalent reconstruction. Remote Sens Environ (2008), 112:1212-1225. http://dx.doi.org/10.1016/j.rse.2007.08.010.

[29] Garen DC, Marks D. Spatially distributed energy balance snowmelt modelling in a mountainous river basin: estimation of meteorological inputs and verification of model results. J Hydrol (2005), 315:126-153. http://dx.doi.org/10.1016/j.jhydrol.2005.03.026. [30] Winther JG. Short-term and long-term variability of snow albedo. Nord Hydrol (1993), 24:199-212. http://dx.doi.org/10.2166/nh.1993.013.

[31] O'Neill ADJ, Gray DM. Spatial and temporal variations of the albedo of prairie snowpack. The Role of Snow and Ice in Hydrology: IAHS/UNESCO/WMO Publication No. 107; 1973. p. 176-186.

[32] Molotch NP, Bales RC. Comparison of ground-based and airborne snow surface albedo parameterizations in an alpine watershed: Impact on snowpack mass balance. Water Resour Res (2006), 42:W05410. http://dx.doi.org/10.1029/2005wr004522. [33] Bair EH, Dozier J, Davis RE, M.T. C, Claffey KJ. CUES-A study site for measuring snowpack energy balance in the Sierra Nevada. Front Earth Sci (2015), 3:38. http://dx.doi.org/10.3389/feart.2015.00058. [34] UCSB/CRREL. Mammoth Mountain Data Page. http://www.snow.ucsb.edu/cues/. [35] Klein AG, Stroeve J. Development and validation of a snow albedo algorithm for the MODIS instrument. Ann Glaciol (2002), 34:45-52. http://dx.doi.org/10.3189/172756402781817662.

[36] Schaaf CB, Gao F, Strahler AH, Lucht W, Li XW, Tsang T, et al. First operational BRDF, albedo nadir reflectance products from MODIS. Remote Sens Environ (2002), 83:135-148. http://dx.doi.org/10.1016/s0034-4257(02)00091-3.

[37] Painter TH, Bryant AC, Skiles SM. Radiative forcing by light absorbing impurities in snow from MODIS surface reflectance data. Geophys Res Lett (2012), 39:L17502. http://dx.doi.org/10.1029/2012GL052457.

[38] Farr TG, Rosen PA, Caro E, Crippen R, Duren R, Hensley S, et al. The Shuttle Radar Topography Mission. Rev Geophys (2007), 45:RG2004.

http://dx.doi.org/10.1029/2005RG000183.

[39] Gesch D, Oimoen M, Greenlee S, Nelson C, Steuck M, Tyler D. The National Elevation Dataset. Photogram Engr Remote Sens (2002), 68:5-11.

[40] Cosgrove BA, Lohmann D, Mitchell KE, Houser PR, Wood EF, Schaake JC, et al. Realtime and retrospective forcing in the North American Land Data Assimilation System (NLDAS) project. J Geophys Res (2003), 108:8842.

http://dx.doi.org/10.1029/2002jd003118. 
[41] Lundquist JD, Cayan DR. Surface temperature patterns in complex terrain: Daily variations and long-term change in the central Sierra Nevada, California.J Geophys Res (2007), 112:D11124. http://dx.doi.org/10.1029/2006JD007561.

[42] Marks D, Dozier J. Climate and energy exchange at the snow surface in the alpine region of the Sierra Nevada, 2, Snow cover energy balance. Water Resour Res (1992),

28:3043-3054. http://dx.doi.org/10.1029/92WR01483.

[43] Dubayah R. Estimating net solar radiation using Landsat Thematic Mapper and digital elevation data. Water Resour Res (1992), 28:2469-2484.

http://dx.doi.org/10.1029/92WR00772.

[44] Erbs DG, Klein SA, Duffie JA. Estimation of the diffuse radiation fraction for hourly, daily and monthly-average global radiation. Solar Energy (1982), 28:293-302. http://dx.doi.org/10.1016/0038-092X(82)90302-4.

[45] Olyphant GA. Insolation topoclimates and potential ablation in alpine snow accumulation basins: Front Range, Colorado. Water Resour Res (1984), 20:491-498. http://dx.doi.org/10.1029/WR020i004p00491.

[46] Bristow KL, Campbell GS, Saxton KE. An equation for seperating daily solar irradiation into direct and diffuse components. Agric For Meteorol (1985), 35:123-131. http://dx.doi.org/10.1016/0168-1923(85)90079-6.

[47] Dubayah R, Loechel S. Modeling topographic solar radiation using GOES data. J Appl Meteorol (1997), 36:141-154. http://dx.doi.org/10.1175/1520-

0450(1997)036<0141:MTSRUG>2.0.CO;2.

[48] Dozier J, Frew J. Rapid calculation of terrain parameters for radiation modeling from digital elevation data. IEEE Trans Geosci Remote Sensing (1990), 28:963-969. http://dx.doi.org/10.1109/36.58986.

[49] Kasten F, Young AT. Revised optical air mass tables and approximation formula. Appl Optics (1989), 28:4735-4738. http://dx.doi.org/10.1364/A0.28.004735.

[50] Marks D, Domingo J, Susong D, Link T, Garen D. A spatially distributed energy balance snowmelt model for application in mountain basins. Hydrol Process (1999), 13:1935-1959. http://dx.doi.org/10.1002/(SICI)10991085(199909)13:12/13<1935::AID-HYP868>3.0.CO;2-C.

[51] Gardner AS, Sharp MJ. A review of snow and ice albedo and the development of a new physically based broadband albedo parameterization. J Geophys Res (2010),

115:F01009. http://dx.doi.org/10.1029/2009jf001444.

[52] Marks D, Dozier J. A clear-sky longwave radiation model for remote alpine areas. Theor Appl Climatol (1979), 27:159-187. http://dx.doi.org/10.1007/BF02243741.

[53] Dozier J, Warren SG. Effect of viewing angle on the infrared brightness temperature of snow. Water Resour Res (1982), 18:1424-1434.

http://dx.doi.org/10.1029/WR018i005p01424.

[54] Raleigh MS, Landry CC, Hayashi M, Quinton WL, Lundquist JD. Approximating snow surface temperature from standard temperature and humidity data: New possibilities for snow model and remote sensing evaluation. Water Resour Res (2013), 49:80538069. http://dx.doi.org/10.1002/2013WR013958.

[55] Kahl A, Winstral A, Marks D, Dozier J. Using satellite imagery and the distributed Isnobal energy balance model to derive SWE heterogeneity in mountainous basins. in: Pomeroy JW, Whitfield PH, Spence C, editors. Putting Prediction in Ungauged Basins into Practice. Ottawa: Canadian Water Resources Association; 2014. p. 243-253. 
[56] RAWS/WRCC. Central Sierra Snow Lab. http://raws.dri.edu/cgibin/rawMAIN.pl?caCSSL.

[57] Flerchinger GN, Xaio W, Marks D, Sauer TJ, Yu Q. Comparison of algorithms for incoming atmospheric long-wave radiation. Water Resour Res (2009), 45:W03423. http://dx.doi.org/10.1029/2008wr007394.

[58] Winstral A. Spatial scaling of snow processes; modeling implications [PhD Thesis]: University of Reading, UK; 2011.

[59] Colbo K, Weller RA. Accuracy of the IMET sensor package in the Subtropics. J Atmos Ocean Technol (2009), 26:1867-1890. http://dx.doi.org/10.1175/2009jtecho667.1. [60] Wan Z, Dozier J. A generalized split-window algorithm for retrieving land-surface temperature from space. IEEE Trans Geosci Remote Sensing (1996), 34:892-905. http://dx.doi.org/10.1109/36.508406.

[61] Painter TH, Dozier J, Roberts DA, Davis RE, Green RO. Retrieval of subpixel snowcovered area and grain size from imaging spectrometer data. Remote Sens Environ (2003), 85:64-77. http://dx.doi.org/10.1016/s0034-4257(02)00187-6.

[62] Molotch NP, Bales RC. SNOTEL representativeness in the Rio Grande headwaters on the basis of physiographics and remotely sensed snow cover persistence. Hydrol Process (2006), 20:723-739. http://dx.doi.org/10.1002/hyp.6128.

[63] Kumar M, Marks D, Dozier J, Reba M, Winstral A. Evaluation of distributed hydrologic impacts of temperature-index and energy-based snow models. Adv Water

Resour (2013), 56:77-89. http://dx.doi.org/10.1016/i.advwatres.2013.03.006. [64] Lopez-Moreno JI, Fassnacht SR, Heath JT, Musselman KN, Revuelto J, Latron J, et al. Small scale spatial variability of snow density and depth over complex alpine terrain: Implications for estimating snow water equivalent. Adv Water Resour (2013), 55:40-52. http://dx.doi.org/10.1016/i.advwatres.2012.08.010.

[65] Elder K, Dozier J, Michaelsen J. Snow accumulation and distribution in an alpine watershed. Water Resour Res (1991), 27:1541-1552.

http://dx.doi.org/10.1029/91WR00506.

[66] Lapo KE, Hinkelman LM, Raleigh MS, Lundquist JD. Impact of errors in the downwelling irradiances on simulations of snow water equivalent, snow surface temperature, and the snow energy balance. Water Resour Res (2015), 51:1649-1670. http://dx.doi.org/10.1002/2014WR016259.

[67] Guan B, Molotch NP, Waliser DE, Jepsen SM, Painter TH, Dozier J. Snow water equivalent in the Sierra Nevada: Blending snow sensor observations with snowmelt model simulations. Water Resour Res (2013), 49:5029-5046.

http://dx.doi.org/10.1002/wrcr.20387.

[68] Lundquist JD, Minder JR, Neiman PJ, Sukovich E. Relationships between Barrier Jet Heights, Orographic Precipitation Gradients, and Streamflow in the Northern Sierra Nevada. J Hydrometeorol (2010), 11:1141-1156. http://dx.doi.org/10.1175/2010JHM1264.1.

[69] Feld SI, Cristea NC, Lundquist JD. Representing atmospheric moisture content along mountain slopes: Examination using distributed sensors in the Sierra Nevada, California. Water Resour Res (2013), 49:4424-4441. http://dx.doi.org/10.1002/wrcr.20318.

[70] Aguado E. Elevational and latitudinal patterns of snow accumulation departures from normal in the Sierra Nevada. Theor Appl Climatol (1990), 42:177-185. http://dx.doi.org/10.1007/BF00866873. 
[71] Shamir E, Georgakakos KP. Estimating snow depletion curves for American River basins using distributed snow modeling. J Hydrol (2007), 334:162-173.

http://dx.doi.org/10.1016/j.jhydrol.2006.10.007.

\section{Tables}


Table 1: Topographic properties of the 18 HUC8 river basins with full natural flow data.

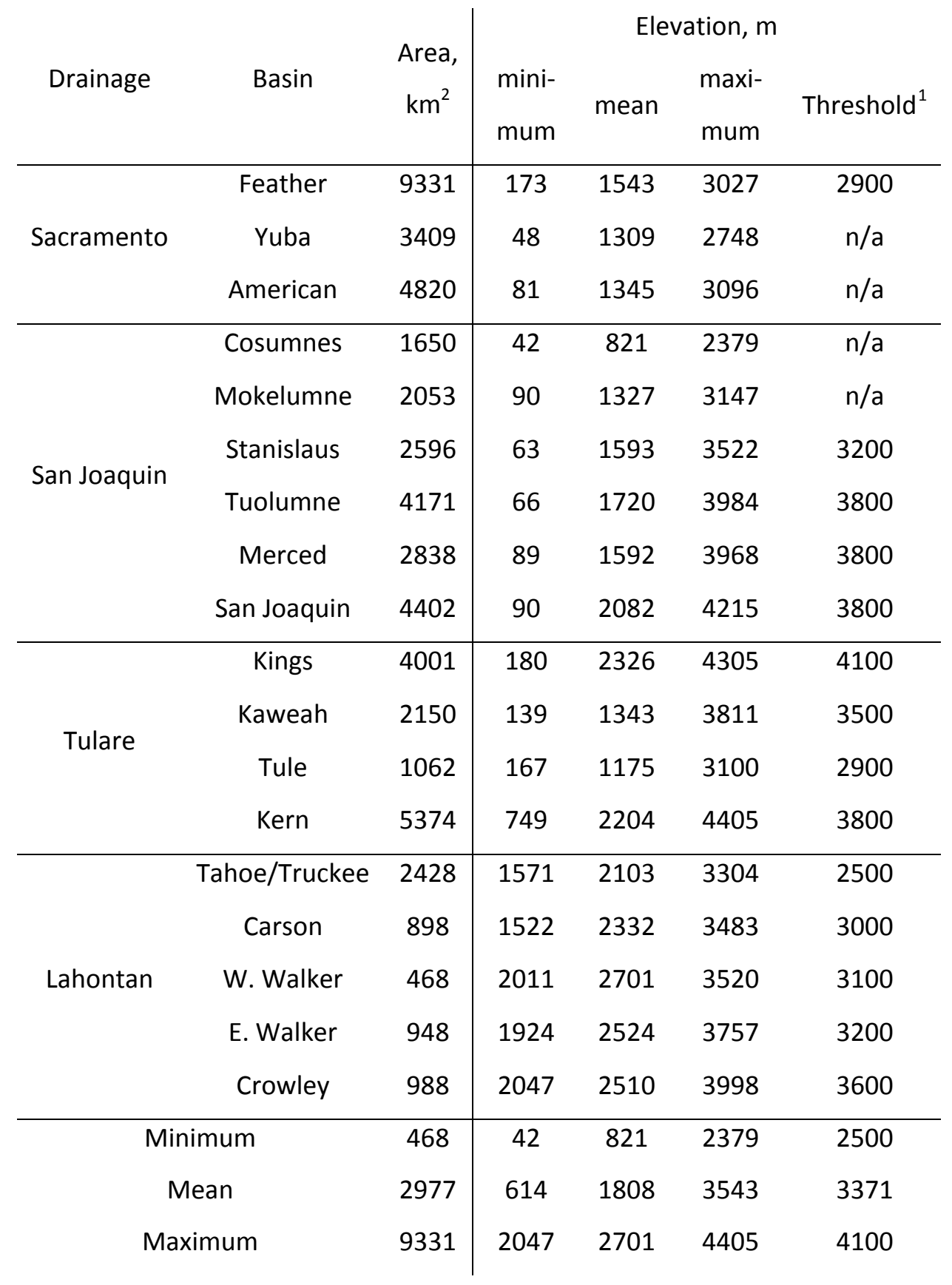

${ }^{1}$ The threshold represents the elevation at which SWE reaches a maximum depth (Section 6). 
Table 2: Vegetation characteristics of the HUC8 basins in Table 1.

\begin{tabular}{|c|c|c|c|c|c|c|}
\hline \multirow[b]{2}{*}{ Drainage } & \multirow[b]{2}{*}{ Basin } & \multicolumn{5}{|c|}{ Vegetation } \\
\hline & & $\begin{array}{l}\text { Coni- } \\
\text { fer }\end{array}$ & Shrub & Barren & $\begin{array}{c}\text { Decidu- } \\
\text { ous }\end{array}$ & Grass \\
\hline \multirow{3}{*}{ Sacramento } & Feather & 0.73 & 0.12 & 0.04 & 0.02 & 0.03 \\
\hline & Yuba & 0.83 & 0.05 & 0.04 & 0.02 & 0.01 \\
\hline & American & 0.76 & 0.07 & 0.05 & 0.05 & 0.01 \\
\hline \multirow{6}{*}{ San Joaquin } & Cosumnes & 0.71 & 0.16 & 0.00 & 0.03 & 0.00 \\
\hline & Mokelumne & 0.71 & 0.12 & 0.03 & 0.06 & 0.01 \\
\hline & Stanislaus & 0.67 & 0.13 & 0.08 & 0.05 & 0.02 \\
\hline & Tuolumne & 0.54 & 0.14 & 0.14 & 0.08 & 0.06 \\
\hline & Merced & 0.55 & 0.15 & 0.08 & 0.12 & 0.06 \\
\hline & San Joaquin & 0.57 & 0.12 & 0.15 & 0.06 & 0.06 \\
\hline \multirow{4}{*}{ Tulare } & Kings & 0.54 & 0.08 & 0.19 & 0.08 & 0.07 \\
\hline & Kaweah & 0.55 & 0.21 & 0.05 & 0.12 & 0.02 \\
\hline & Tule & 0.54 & 0.21 & 0.01 & 0.18 & 0.02 \\
\hline & Kern & 0.45 & 0.23 & 0.15 & 0.06 & 0.08 \\
\hline \multirow{5}{*}{ Lahontan } & Tahoe/Truckee & 0.57 & 0.07 & 0.25 & 0.00 & 0.02 \\
\hline & Carson & 0.62 & 0.22 & 0.10 & 0.01 & 0.02 \\
\hline & W. Walker & 0.44 & 0.24 & 0.21 & 0.02 & 0.07 \\
\hline & E. Walker & 0.33 & 0.40 & 0.12 & 0.05 & 0.08 \\
\hline & Owens & 0.40 & 0.34 & 0.14 & 0.03 & 0.06 \\
\hline \multicolumn{2}{|c|}{ Minimum } & 0.33 & 0.05 & 0.00 & 0.00 & 0.00 \\
\hline \multicolumn{2}{|c|}{ Mean } & 0.58 & 0.17 & 0.10 & 0.06 & 0.04 \\
\hline \multicolumn{2}{|c|}{ Maximum } & 0.83 & 0.40 & 0.25 & 0.18 & 0.08 \\
\hline
\end{tabular}


Table 3: Individual station results for evaluation of incoming solar radiation and air temperature.

\begin{tabular}{|c|c|c|c|c|c|c|c|c|c|}
\hline \multirow[t]{2}{*}{ Site } & \multicolumn{3}{|c|}{ location } & \multicolumn{3}{|c|}{$\begin{array}{r}\text { Solar Radiation, } \mathrm{Wm}^{-2} \\
\text { differences }\end{array}$} & \multicolumn{3}{|c|}{$\begin{array}{l}\text { Air Temperature } \\
\text { differences }\end{array}$} \\
\hline & elevation & latitude & longitude & RMSE & mean & median & RMSE & mean & median \\
\hline bgd & 1731 & 40.590 & -121.080 & 34 & 18 & 19 & 2.3 & 1.3 & 1.1 \\
\hline bgr & 244 & 39.381 & -121.386 & 34 & 4 & 4 & 1.9 & 0.4 & 0.4 \\
\hline bke & 2301 & 35.451 & -118.584 & 35 & 8 & 7 & 2.6 & -0.8 & -0.6 \\
\hline bkk & 2499 & 36.093 & -118.261 & 32 & 11 & 9 & 1.7 & -0.9 & -0.8 \\
\hline btn & 1661 & 37.843 & -118.478 & 34 & 9 & 6 & 2.1 & -0.4 & -0.5 \\
\hline btt & 963 & 37.383 & -119.617 & 34 & 2 & -1 & 1.9 & -1.5 & -1.6 \\
\hline bve & 1524 & 38.483 & -120.317 & 38 & 6 & 1 & - & - & - \\
\hline bvy & 1219 & 35.140 & -118.625 & 36 & 12 & 6 & - & - & - \\
\hline car & 1467 & 40.069 & -121.582 & 50 & 36 & 34 & 2.8 & -2.2 & -2.3 \\
\hline chi & 70 & 39.712 & -121.783 & 39 & 15 & 11 & 2.0 & 0.6 & 0.5 \\
\hline $\mathrm{crg}$ & 90 & 39.939 & -122.170 & 43 & 25 & 23 & 2.4 & 1.1 & 1.0 \\
\hline cvr & 366 & 37.380 & -120.077 & 42 & 11 & 3 & 1.6 & 0.2 & 0.2 \\
\hline cvw & 2316 & 37.745 & -118.983 & 41 & 0 & -11 & 2.0 & 0.5 & 0.2 \\
\hline dan & 2987 & 37.897 & -119.257 & 41 & -6 & -19 & 1.3 & -0.1 & 0.0 \\
\hline dpo & 2307 & 37.629 & -119.085 & 51 & -41 & -48 & - & - & - \\
\hline dye & 1292 & 40.022 & -120.106 & 60 & 20 & 9 & 2.5 & -0.4 & -0.3 \\
\hline epk & 367 & 39.367 & -122.517 & 53 & 34 & 24 & 1.9 & 1.1 & 1.0 \\
\hline ery & 2940 & 37.933 & -119.233 & 35 & -19 & -25 & 1.7 & -0.8 & -1.0 \\
\hline $\mathrm{fml}$ & 1265 & 35.872 & -117.918 & 35 & 5 & 0 & 2.4 & -2.1 & -2.2 \\
\hline hrk & 1890 & 40.418 & -121.275 & 41 & -25 & -32 & - & - & - \\
\hline iwc & 1219 & 35.685 & -117.889 & 47 & -3 & -19 & 2.4 & -2.1 & -2.2 \\
\hline jar & 823 & 39.736 & -121.489 & 41 & -23 & -25 & 1.9 & -1.2 & -1.1 \\
\hline juc & 1433 & 41.328 & -120.467 & 43 & -8 & -18 & 1.6 & -0.4 & -0.4 \\
\hline jwb & 1311 & 35.295 & -118.226 & 53 & 36 & 29 & 2.2 & 1.2 & 1.3 \\
\hline las & 1256 & 40.350 & -121.700 & 49 & -13 & -28 & 2.4 & -1.6 & -1.7 \\
\hline Ibn & 107 & 37.053 & -121.049 & 46 & -24 & -36 & 2.5 & 1.5 & 1.2 \\
\hline Irm & 1338 & 35.478 & -117.699 & 48 & 21 & 8 & 1.9 & -0.1 & -0.1 \\
\hline $\mathrm{mtf}$ & 1250 & 37.054 & -119.371 & 40 & -15 & -25 & - & - & - \\
\hline qua & 2195 & 36.122 & -118.545 & 44 & -24 & -36 & 1.9 & 1.1 & 1.2 \\
\hline qyr & 1067 & 39.975 & -120.941 & 45 & -5 & -15 & 1.8 & 0.5 & 0.5 \\
\hline rav & 1615 & 40.731 & -120.316 & 76 & 60 & 56 & 1.4 & -0.6 & -0.6 \\
\hline rdh & 617 & 39.304 & -121.117 & 49 & -19 & -30 & 1.5 & -0.8 & -0.7 \\
\hline rkc & 2146 & 37.551 & -118.667 & 79 & 65 & 52 & 2.4 & -1.0 & -1.4 \\
\hline
\end{tabular}




\begin{tabular}{|c|c|c|c|c|c|c|c|c|c|}
\hline \multirow[t]{2}{*}{ Site } & \multicolumn{3}{|c|}{ location } & \multicolumn{3}{|c|}{$\begin{array}{r}\text { Solar Radiation, } \mathrm{Wm}^{-2} \\
\text { differences }\end{array}$} & \multicolumn{3}{|c|}{$\begin{array}{l}\text { Air Temperature } \\
\text { differences }\end{array}$} \\
\hline & elevation & latitude & longitude & RMSE & mean & median & RMSE & mean & median \\
\hline san & 20 & 37.182 & -120.794 & 43 & 13 & 4 & - & - & - \\
\hline tes & 3031 & 37.911 & -119.257 & 52 & 16 & -1 & 1.3 & -0.6 & -0.7 \\
\hline tum & 2621 & 37.873 & -119.350 & 48 & 26 & 16 & 2.0 & 1.1 & 1.2 \\
\hline tvl & 1647 & 39.979 & -120.479 & 51 & -18 & -36 & 3.7 & 2.3 & 2.6 \\
\hline wed & 893 & 41.479 & -122.455 & 45 & 21 & 13 & 1.9 & -0.1 & -0.5 \\
\hline wht & 748 & 40.619 & -121.899 & 46 & -6 & -22 & 2.3 & -1.0 & -0.7 \\
\hline wkp & 1698 & 35.666 & -118.057 & 69 & -24 & -46 & 1.7 & -0.2 & -0.1 \\
\hline wtc & 1317 & 39.317 & -120.838 & 54 & 25 & 14 & 2.9 & -2.4 & -2.4 \\
\hline $\begin{array}{l}\text { Mini } \\
\text { mum } \\
\text { Avera }\end{array}$ & 20 & 35.14 & -122.517 & 32 & -41 & -48 & 1.3 & -2.4 & -2.4 \\
\hline $\begin{array}{c}\text { ge } \\
\text { Maxi }\end{array}$ & 1411 & 38.293 & -120.023 & 46 & 5 & -3 & 2.1 & -0.2 & -0.3 \\
\hline mum & 3031 & 41.479 & -117.699 & 79 & 65 & 56 & 3.7 & 2.3 & 2.6 \\
\hline
\end{tabular}


Table 4: Individual station results for evaluation of NLDAS2 incoming longwave radiation.

\begin{tabular}{c|ccc|ccc} 
Site & $\begin{array}{c}\text { elevation } \\
(\mathrm{m})\end{array}$ & latitude & longitude & RMSE & $\begin{array}{c}\mid c \\
\text { Error Statistics, } \mathrm{Wm}^{-2} \\
\text { difference }\end{array}$ & $\begin{array}{c}\text { median } \\
\text { difference }\end{array}$ \\
\hline rno & 1366 & 39.539 & -119.806 & 58 & -56 & -58 \\
tah1 & 1900 & 39.181 & -120.119 & 30 & -23 & -24 \\
tah2 & 1900 & 39.181 & -120.119 & 26 & -17 & -16
\end{tabular}


Table 5: Yearly and summary statistics for evaluation of maximum SWE accumulation with snow courses. Statistics are reported in $\mathrm{mm}$.

\begin{tabular}{|c|c|c|c|}
\hline & \multicolumn{3}{|c|}{ Mean of $3 \times 3$} \\
\hline & RMSE & $\begin{array}{c}\text { mean } \\
\text { difference }\end{array}$ & $\begin{array}{c}\text { median } \\
\text { difference }\end{array}$ \\
\hline 2000 & 348 & 236 & 213 \\
\hline 2001 & 315 & 224 & 203 \\
\hline 2002 & 223 & 40 & 15 \\
\hline 2003 & 351 & 214 & 182 \\
\hline 2004 & 225 & 0 & -9 \\
\hline 2005 & 338 & 40 & 40 \\
\hline 2006 & 380 & 83 & 30 \\
\hline 2007 & 265 & 180 & 157 \\
\hline 2008 & 232 & -79 & -79 \\
\hline 2009 & 253 & 96 & 77 \\
\hline 2010 & 312 & 113 & 98 \\
\hline 2011 & 315 & 38 & 31 \\
\hline Minimum & 223 & -79 & -79 \\
\hline Mean & 297 & 99 & 80 \\
\hline Maximum & 380 & 236 & 213 \\
\hline
\end{tabular}


Table 6: Maximum SWE accumulation error summarized by latitude and elevation. Statistics are reported in $\mathrm{mm}$.

\begin{tabular}{c|cc|c|cc} 
Latitude & $\begin{array}{c}\text { mean } \\
\text { difference }\end{array}$ & $\begin{array}{c}\text { median } \\
\text { difference }\end{array}$ & Elevation & $\begin{array}{c}\text { mean } \\
\text { difference }\end{array}$ & $\begin{array}{c}\text { median } \\
\text { difference }\end{array}$ \\
\hline 40.5 & 173 & 161 & 3500 & 189 & 18 \\
40.0 & 82 & 71 & 3250 & 65 & 32 \\
39.5 & 99 & 35 & 3000 & 123 & 53 \\
39.0 & 169 & 136 & 2750 & 28 & 6 \\
38.5 & 116 & 94 & 2500 & -16 & -1 \\
38.0 & 18 & 6 & 2250 & 53 & 15 \\
37.5 & 20 & 2 & 2000 & 89 & 48 \\
37.0 & 71 & 3 & 1750 & 189 & 162 \\
36.5 & -6 & -1 & 1500 & 149 & 157 \\
36.0 & 12 & 6 & 1250 & 111 & 55 \\
\hline
\end{tabular}


Table 7: Characteristics of the 10 survey sites, survey SWE, and model SWE.

\begin{tabular}{|c|c|c|c|c|c|c|}
\hline Site & $\begin{array}{c}2010 \\
\text { Survey } \\
\text { Date }\end{array}$ & $\begin{array}{c}\text { Latitude, } \\
\circ\end{array}$ & $\begin{array}{c}\text { Longitude, } \\
\circ\end{array}$ & $\begin{array}{c}\text { Elevation, } \\
\mathrm{m}\end{array}$ & $\begin{array}{c}\text { Slope, } \\
\circ\end{array}$ & $\underset{0}{\text { Aspect }}{ }^{1}$ \\
\hline Lincoln Mountain & 17 April & 39.2842 & -120.3364 & 2207 & 21 & 90 \\
\hline Pyramid Peak & 19 April & 38.8351 & -120.1544 & 2663 & 15 & 23 \\
\hline Wagon Wheel 1 & 23 April & 38.6552 & -120.0505 & 2782 & 19 & 138 \\
\hline Wagon Wheel 2 & 23 April & 38.6553 & -120.0564 & 2688 & 13 & 119 \\
\hline Kirkwood & 24 April & 38.6732 & -120.0793 & 2720 & 13 & 128 \\
\hline Granite Chief & 25 April & 39.1992 & -120.3058 & 2555 & 20 & 150 \\
\hline Carson Pass 1 & 30 April & 38.6687 & -120.0045 & 2848 & 18 & -30 \\
\hline Carson Pass 2 & 30 April & 38.6733 & -120.0103 & 2799 & 12 & 24 \\
\hline Castle Peak 1 & 3 May & 39.3880 & -120.3647 & 2595 & 10 & -26 \\
\hline \multirow[t]{2}{*}{ Castle Peak 2} & 3 May & 39.3880 & -120.3706 & 2589 & 13 & 54 \\
\hline & $\begin{array}{c}\text { Srad } \\
\mathrm{MJ} / \mathrm{m}^{2}\end{array}$ & $\begin{array}{c}\text { Survey } \\
\text { SWE, mm }\end{array}$ & $\begin{array}{l}\text { Predicted }^{2} \\
\text { SWE, mm }\end{array}$ & $\begin{array}{c}\text { Best } \\
\text { Recon- } \\
\text { structed } \\
\text { SWE, mm }\end{array}$ & & \\
\hline Lincoln Mountain & 1778 & 1143 & 1256 & 1156 & & \\
\hline Pyramid Peak & 2111 & 1447 & 1522 & 1355 & & \\
\hline Wagon Wheel 1 & 2140 & 904 & 985 & 1372 & & \\
\hline Wagon Wheel 2 & 1974 & 989 & 961 & 1461 & & \\
\hline Kirkwood & 2057 & 1059 & 1040 & 1166 & & \\
\hline Granite Chief & 1722 & 1344 & 1347 & 1722 & & \\
\hline Carson Pass 1 & 1351 & 1521 & 1528 & 1540 & & \\
\hline Carson Pass 2 & 1481 & 1219 & 1225 & 1330 & & \\
\hline Castle Peak 1 & 1299 & 1961 & 1970 & 1804 & & \\
\hline Castle Peak 2 & 1506 & 1670 & 1680 & 1665 & & \\
\hline
\end{tabular}

\footnotetext{
${ }^{1}$ Aspect is $0^{\circ}$ at south, positive counter-clockwise

${ }^{2}$ Predicted SWE is calculated using the regression equation in Section 5.4
} 

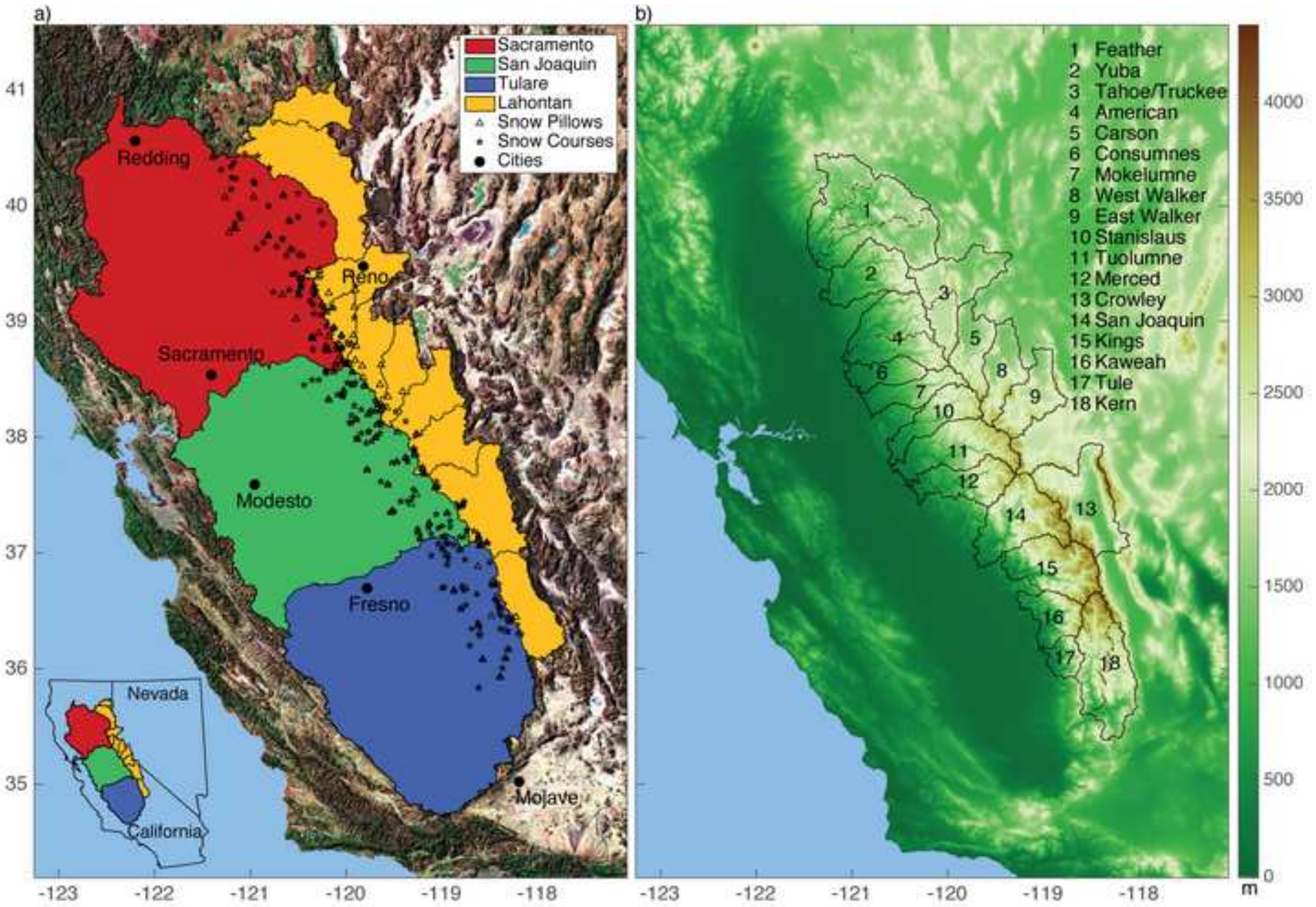

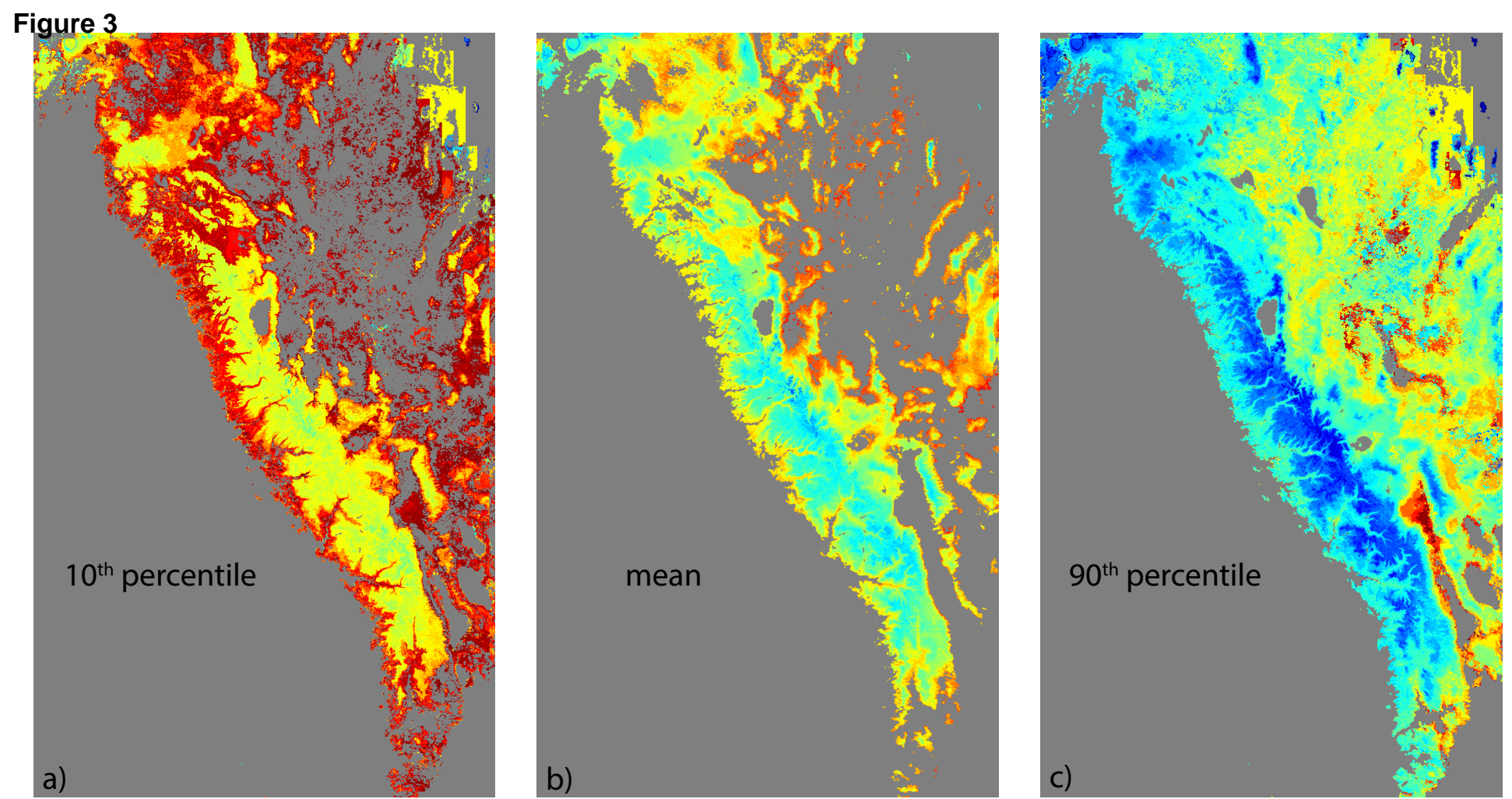

May 1
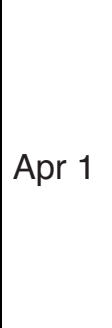

Mar 1

Feb 1

c) 
Figure 4 March 1
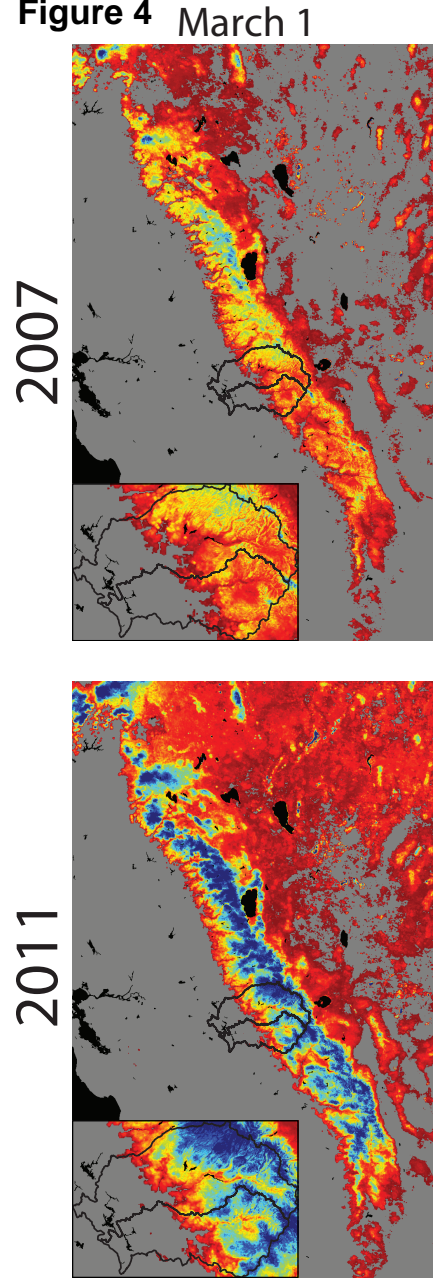

April 1

May 1

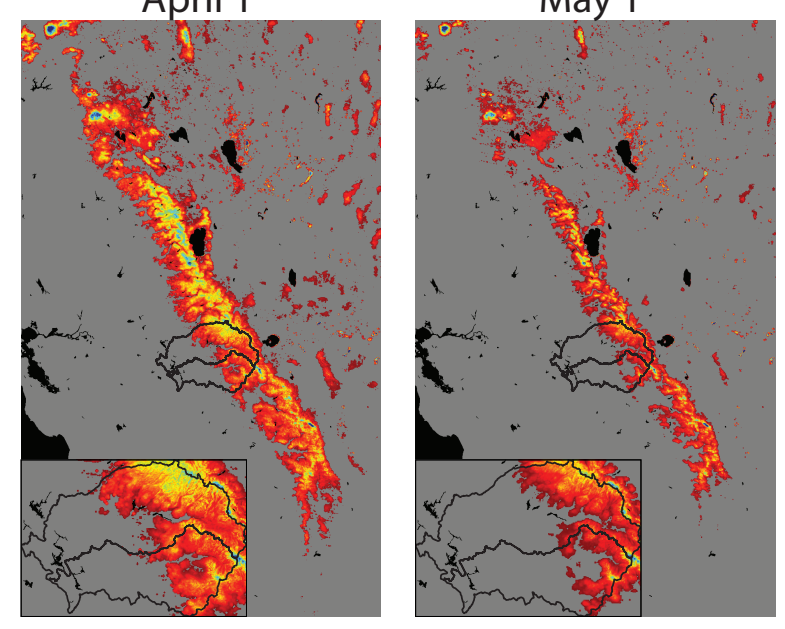

June 1

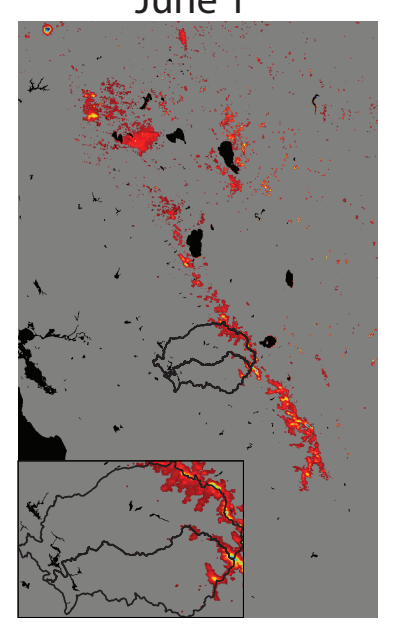

July 1
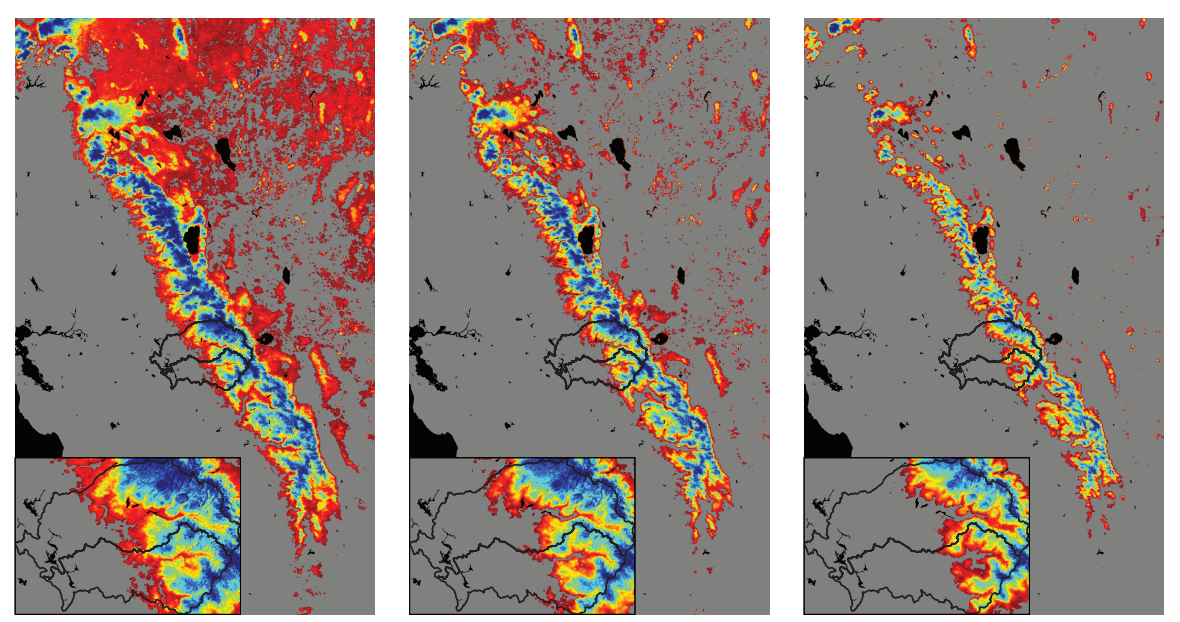

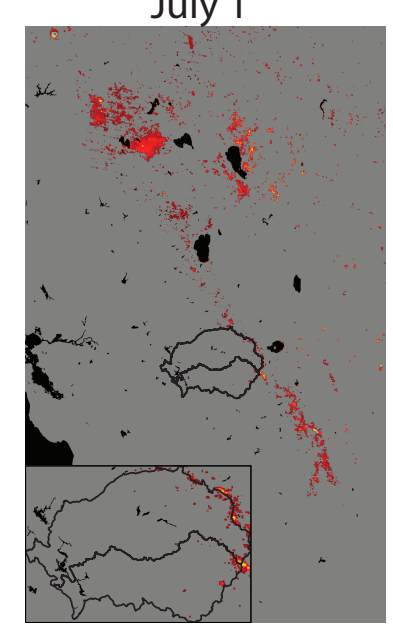

1750

1500

1250

1000

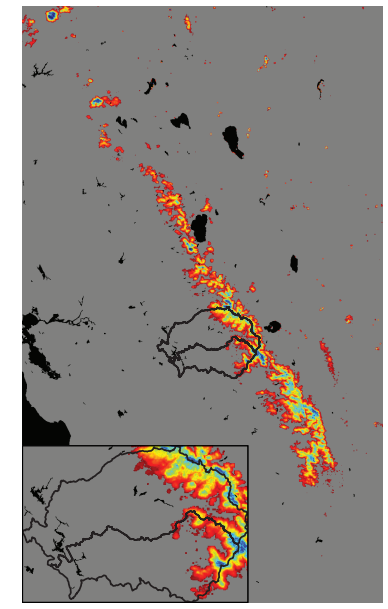

$-750$

500

250

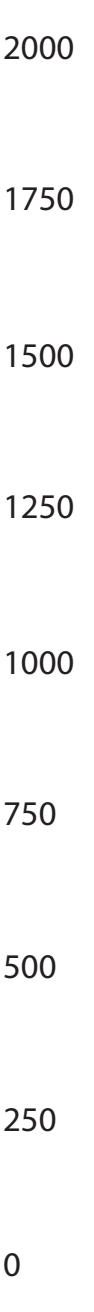



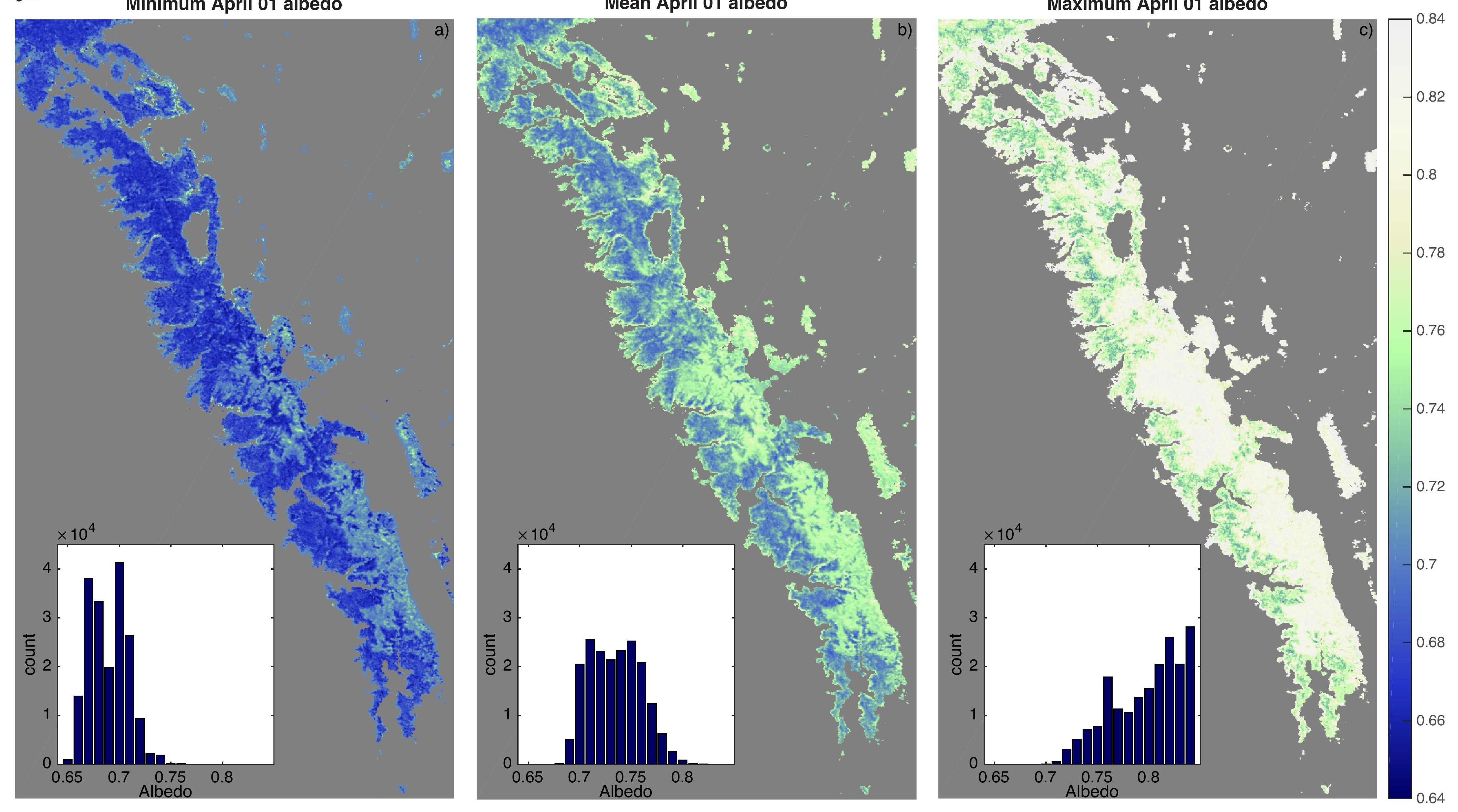
Figure 9

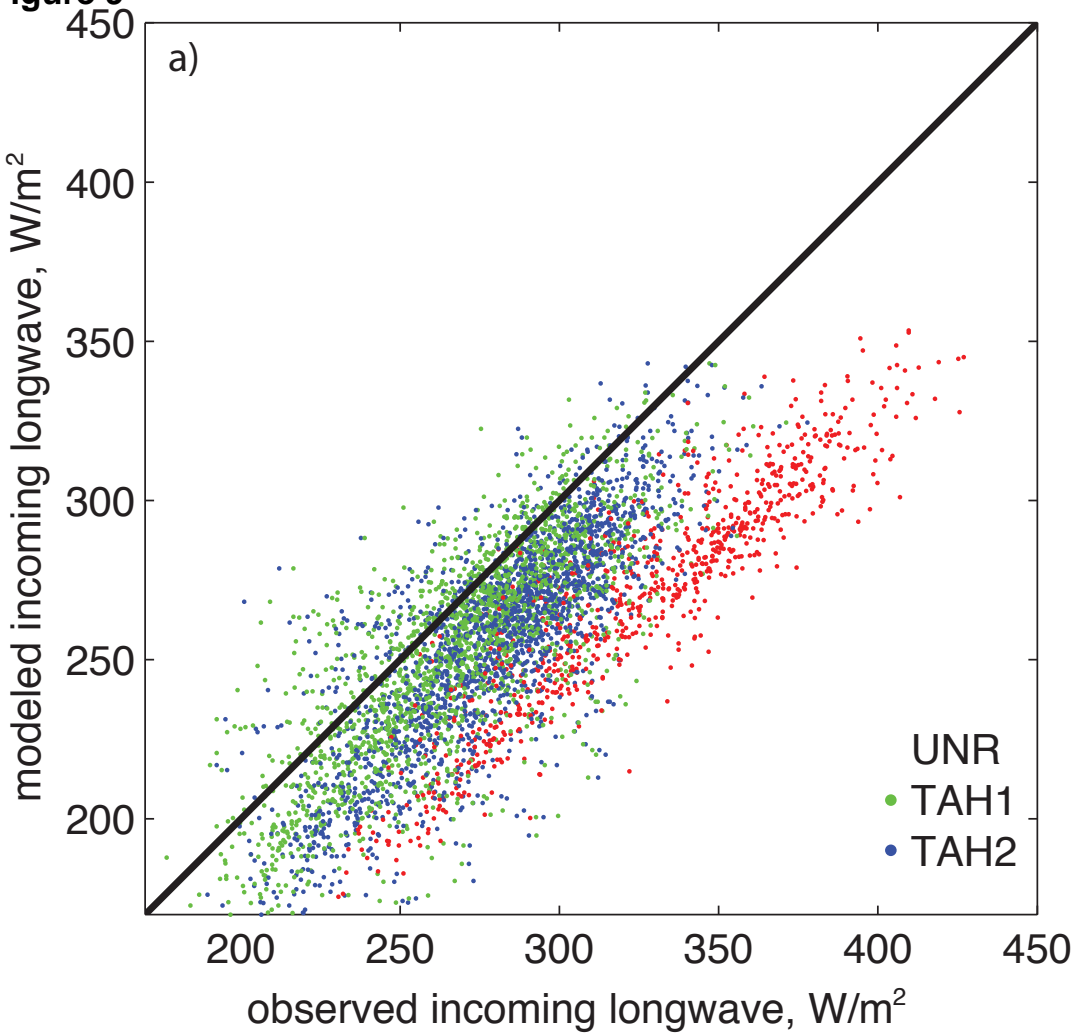




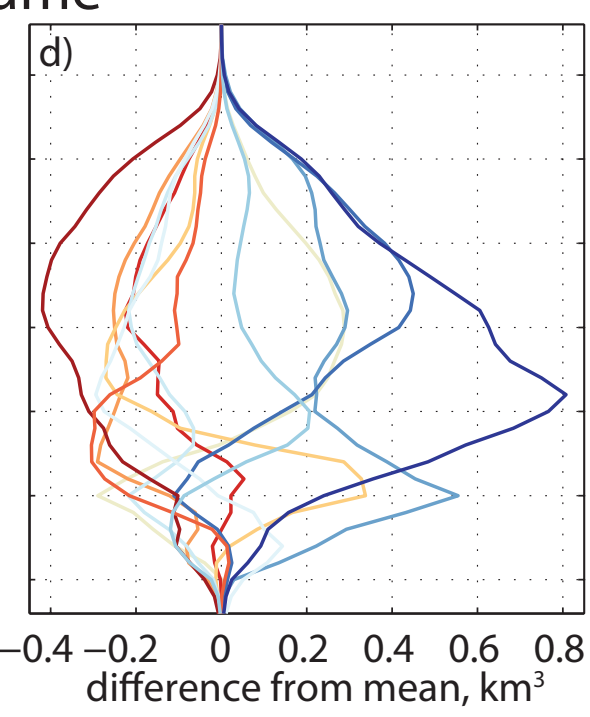
difference from mean, $\mathrm{km}^{3}$
Figure 12

\section{Depth}

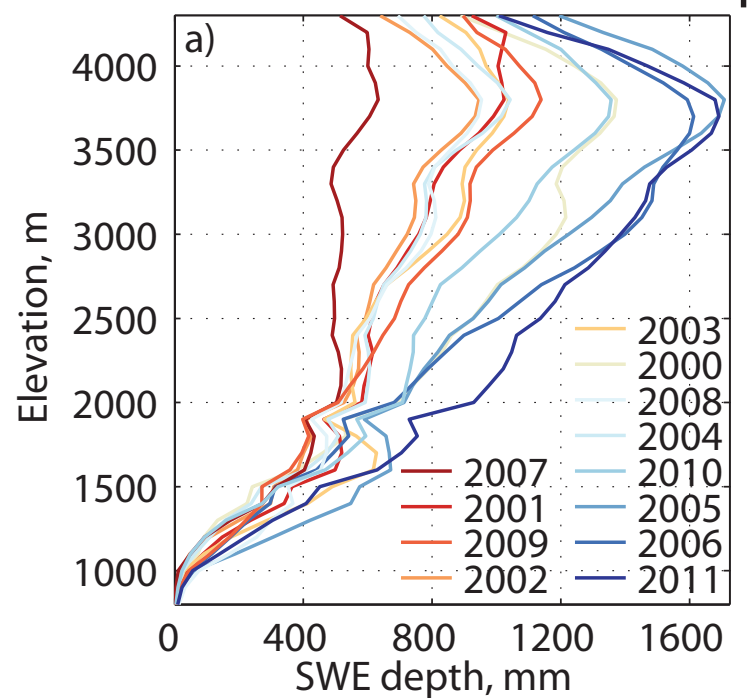
SWE depth, mm

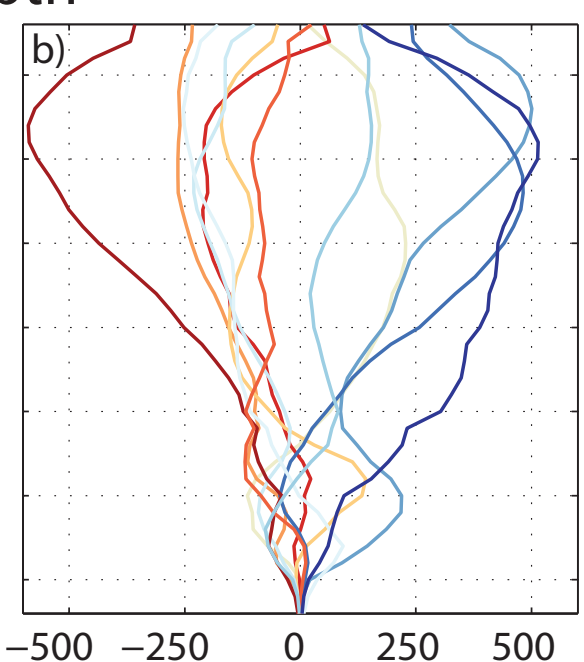
difference from mean, $\mathrm{mm}$

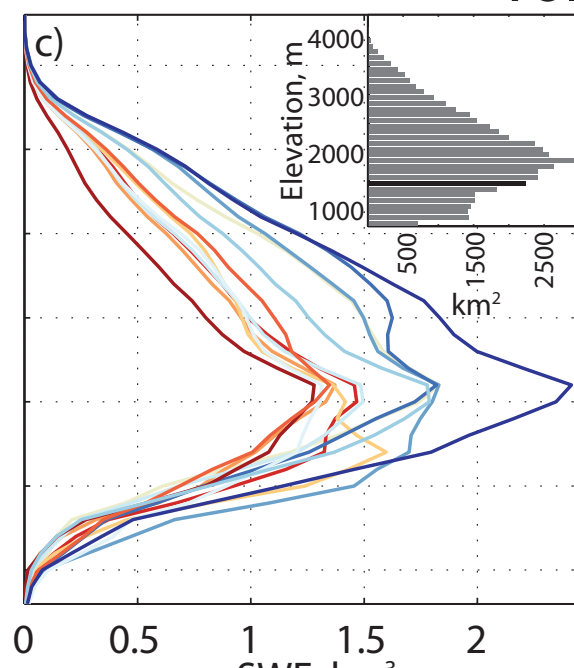

SWE, $\mathrm{km}^{3}$

\section{Volume}


Figure 13

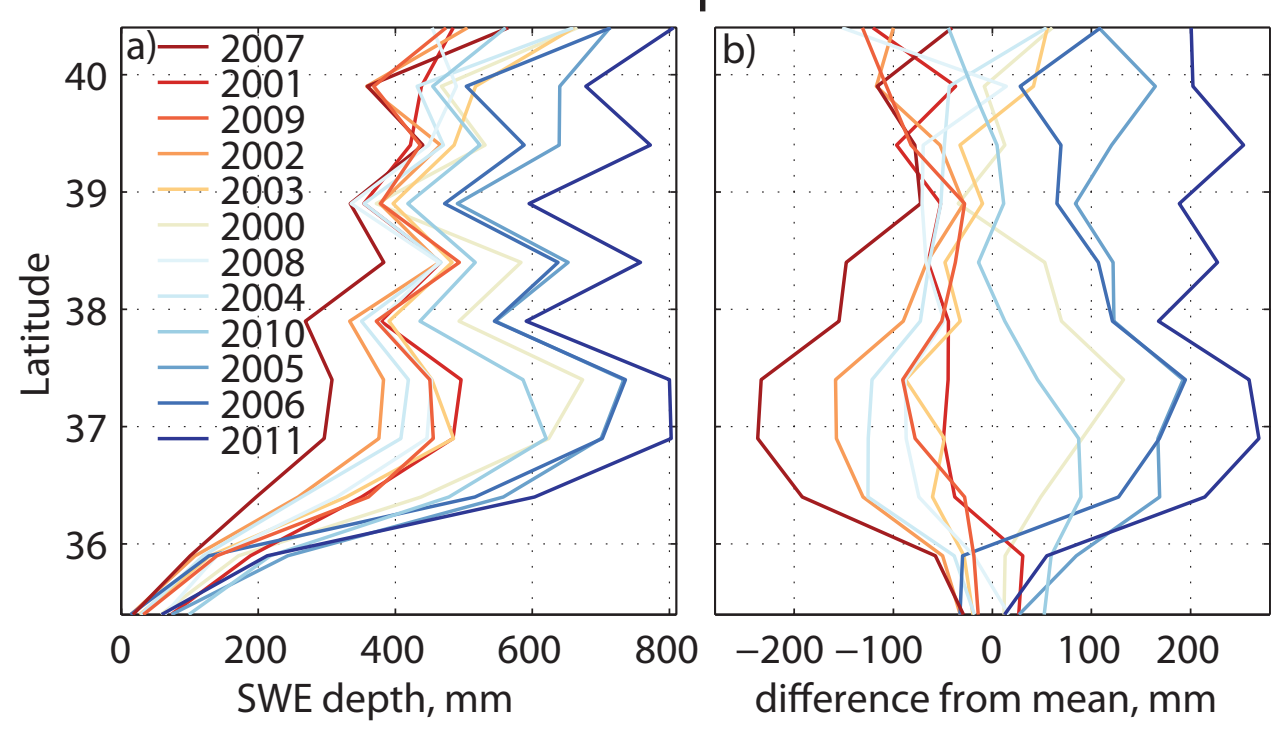

Volume

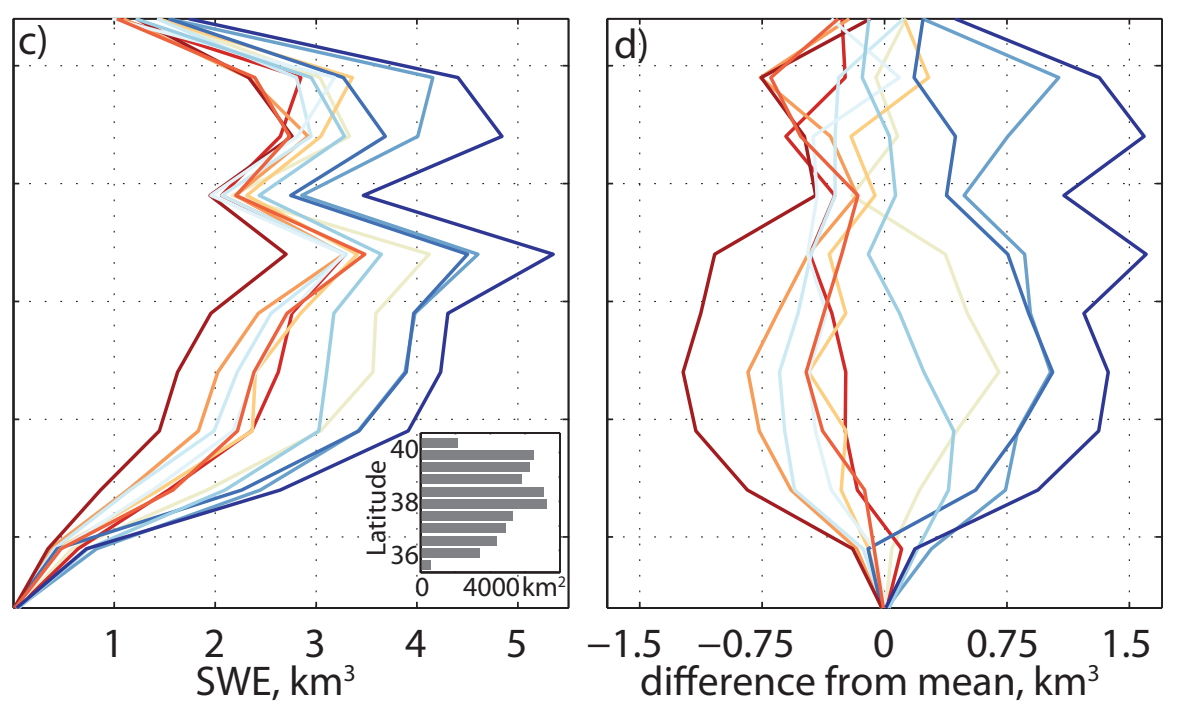


Figure 14

Depth

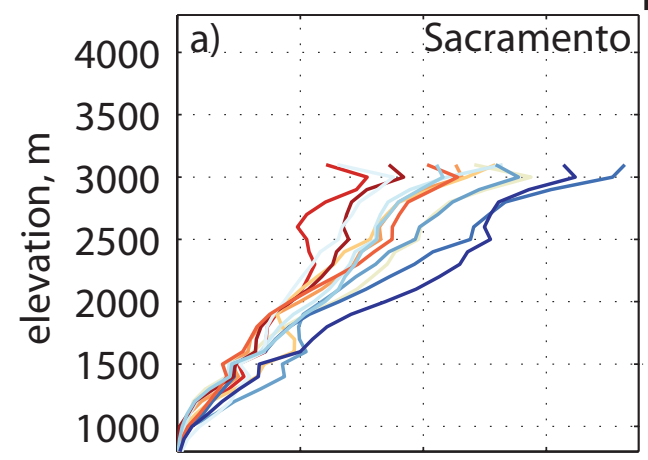

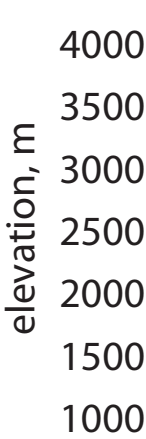

ह

4000

3500

3000

으 2500

2000

1500

1000

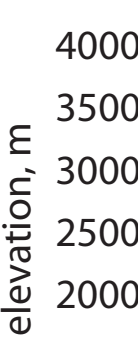

1500

1000
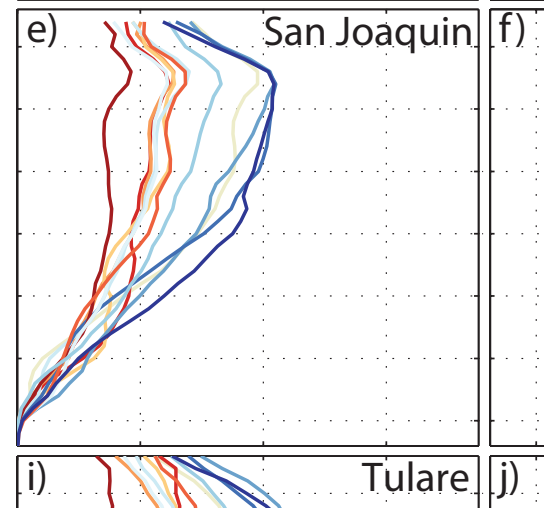

i)

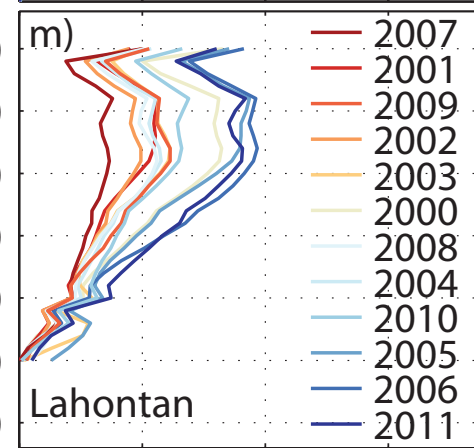

0
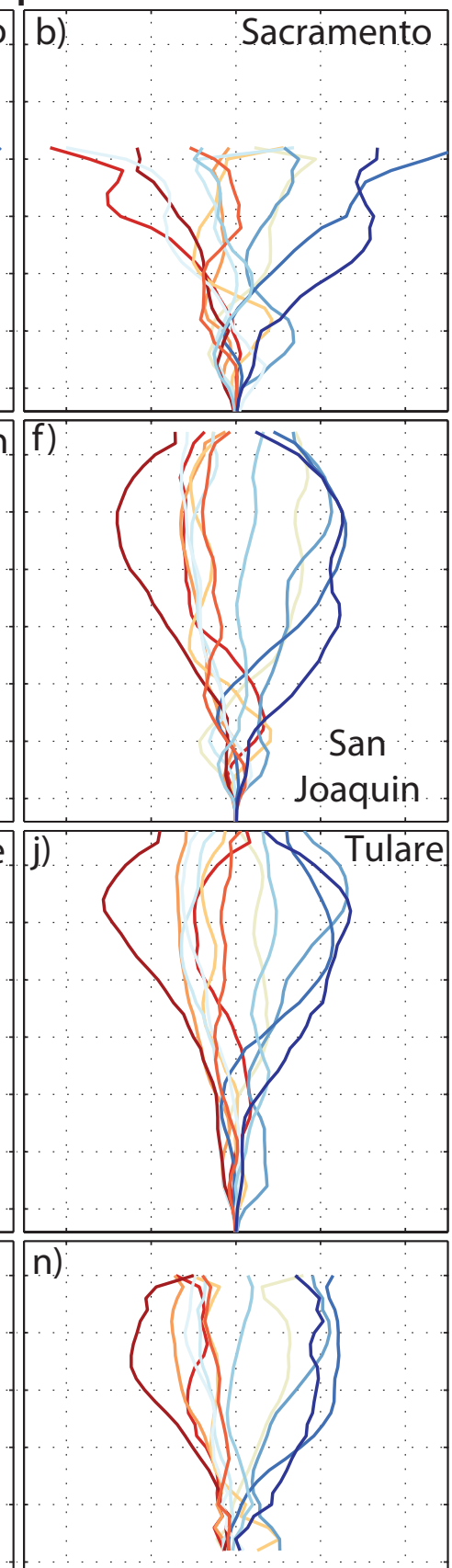

Lahontan
Volume
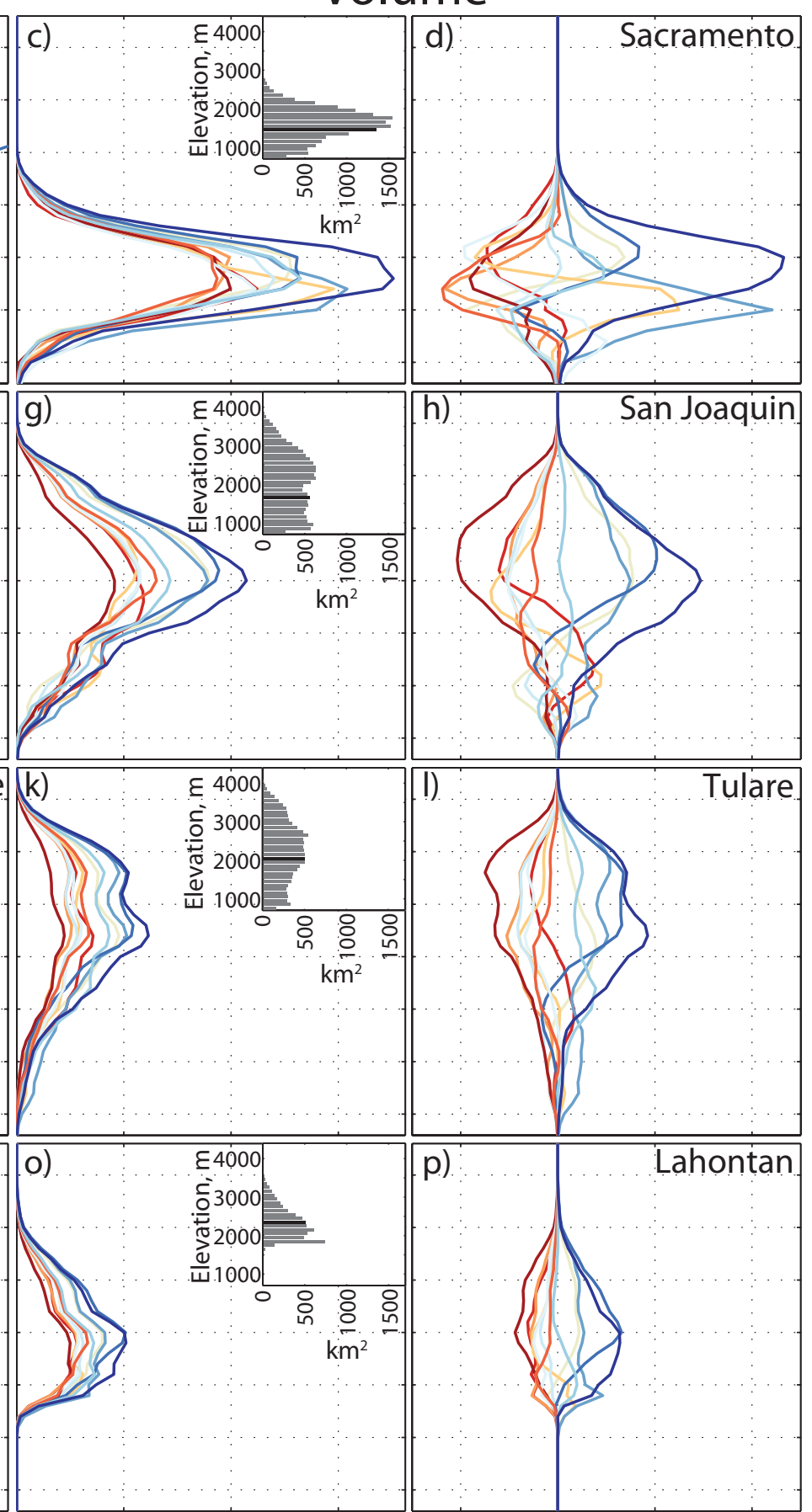

$\begin{array}{lll}0.4 & 0.8 & 1.2\end{array}$ SWE volume, $\mathrm{km}^{3}$

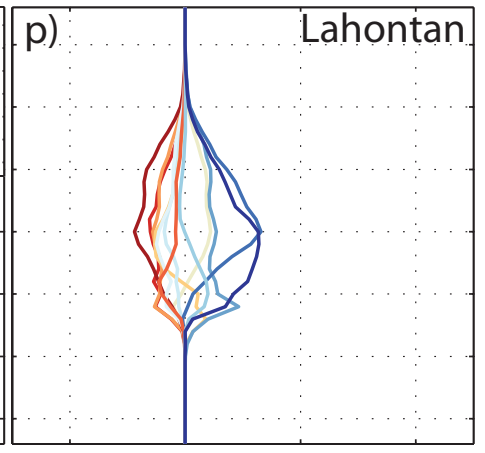

$\begin{array}{llll}-0.2 & 0 & 0.2 & 0.4\end{array}$ difference from mean, $\mathrm{km}^{3}$ 
Figure 15
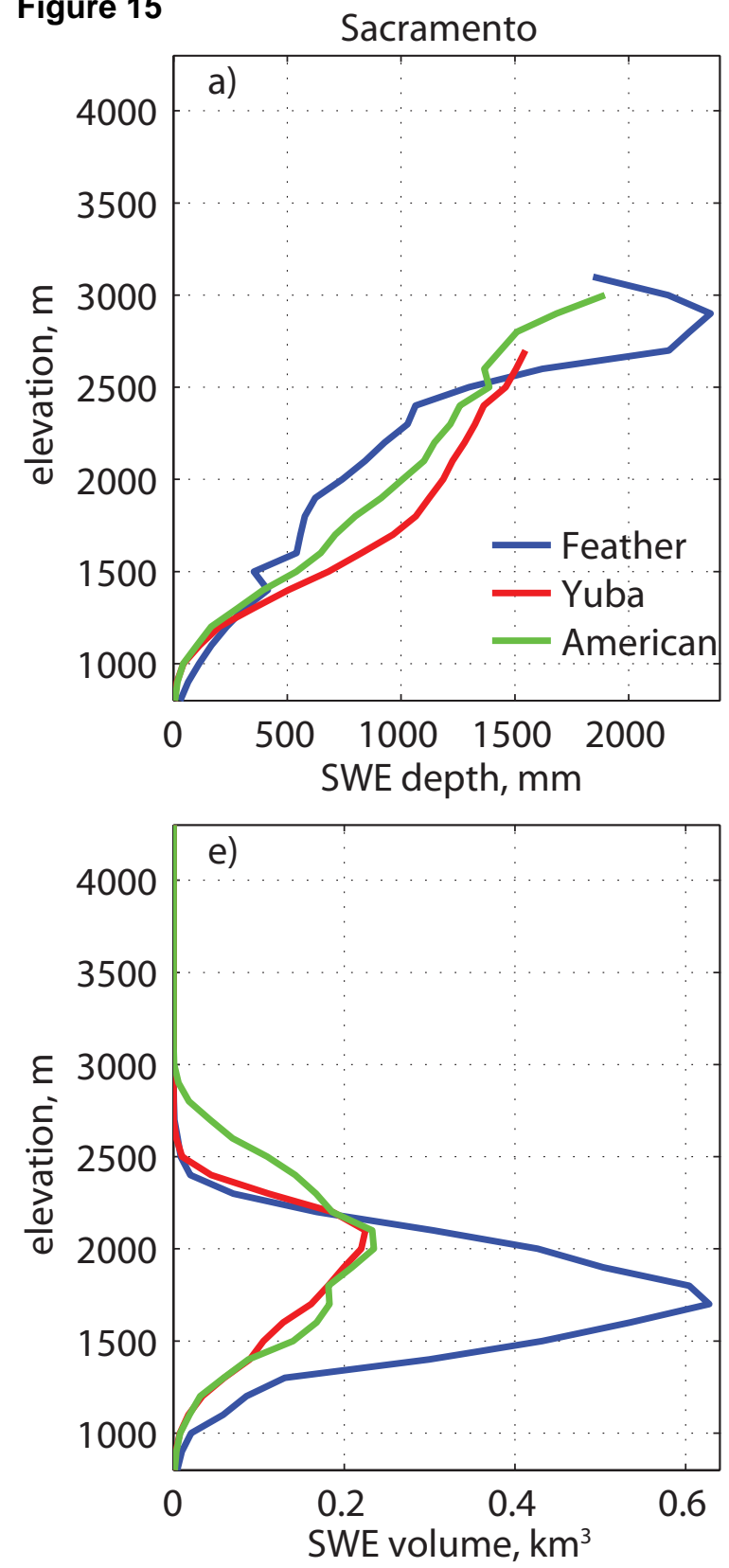

San Joaquin
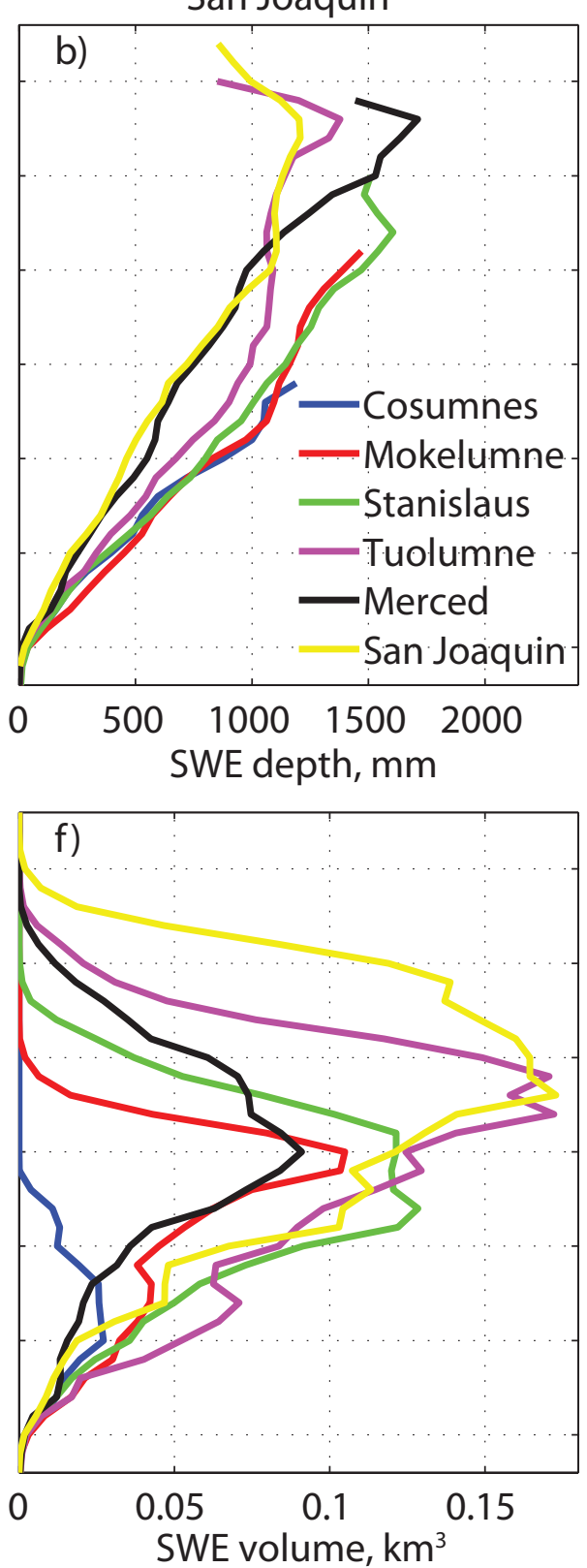

Tulare
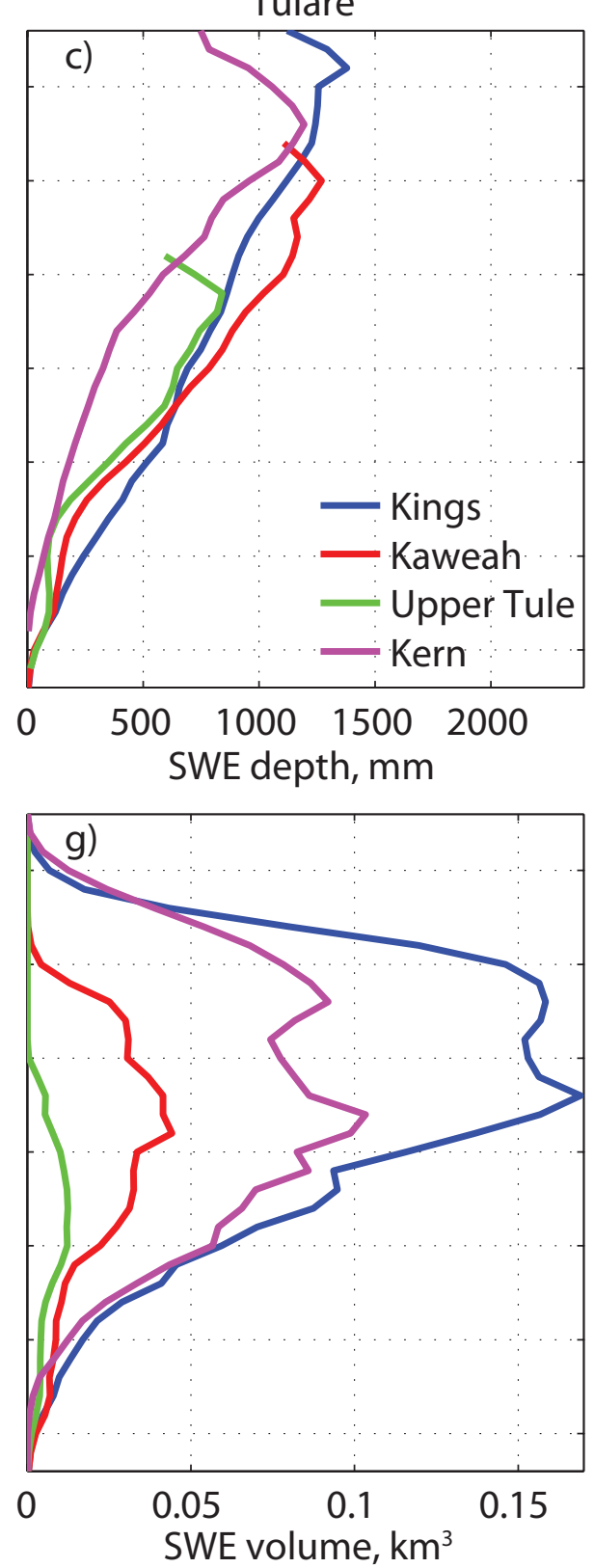

Lahontan
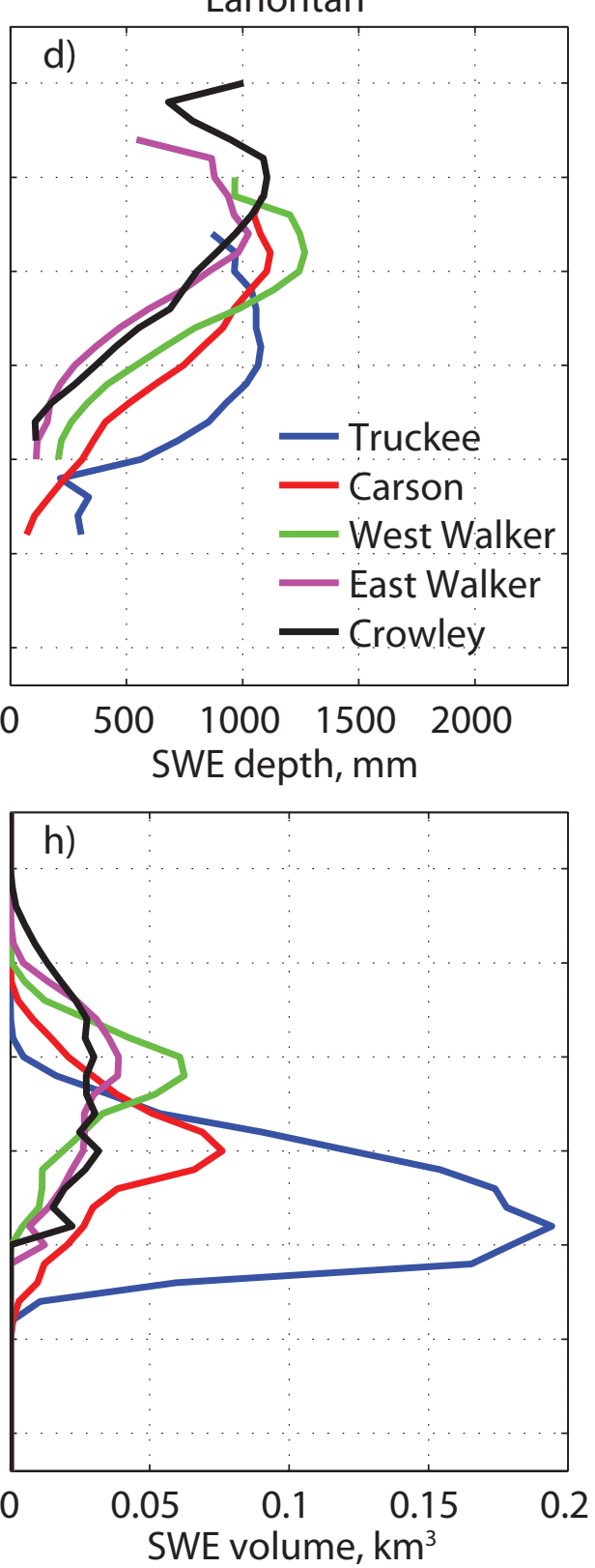


\section{Figure 17}
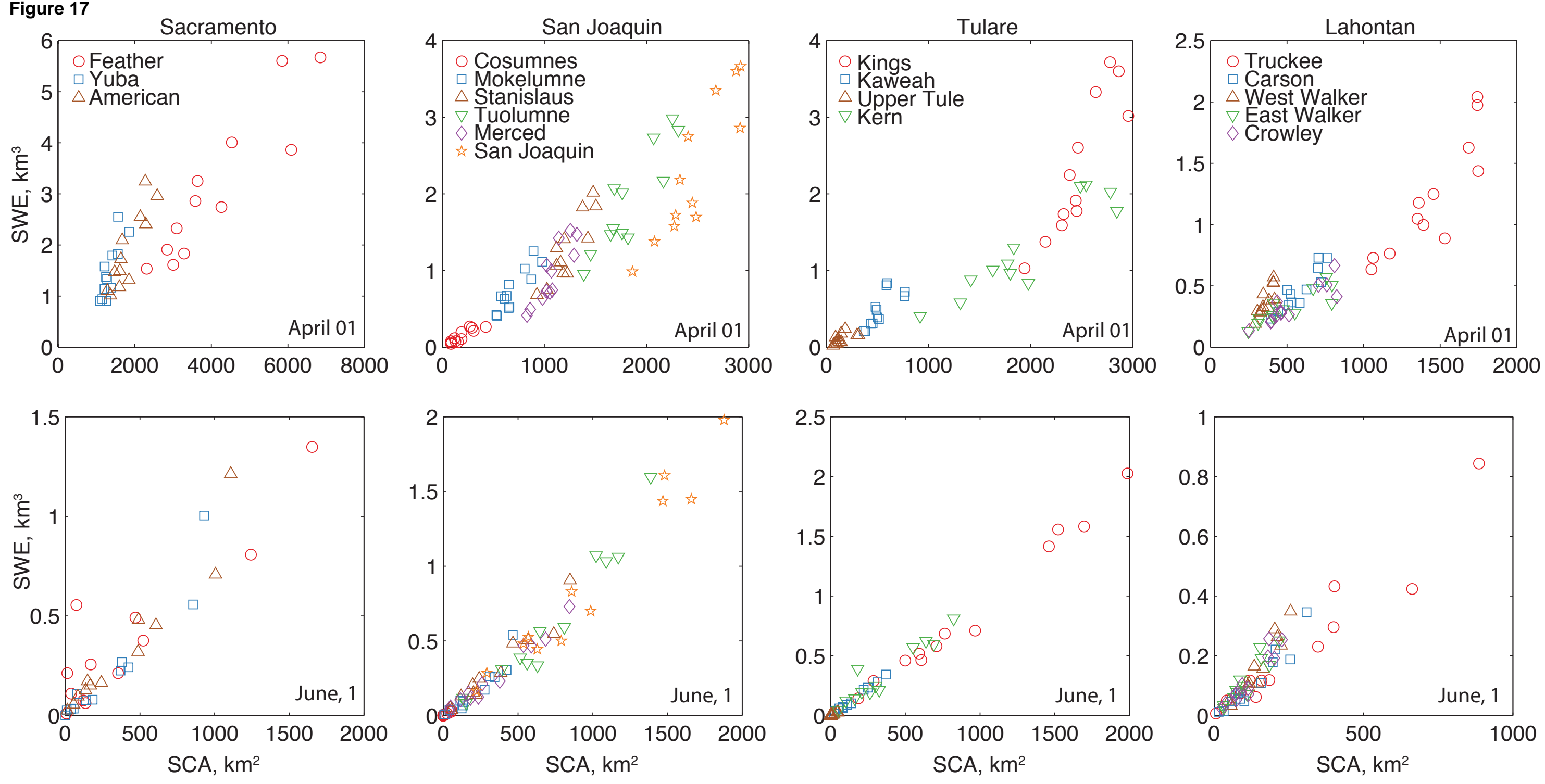


\section{Figứre 18}

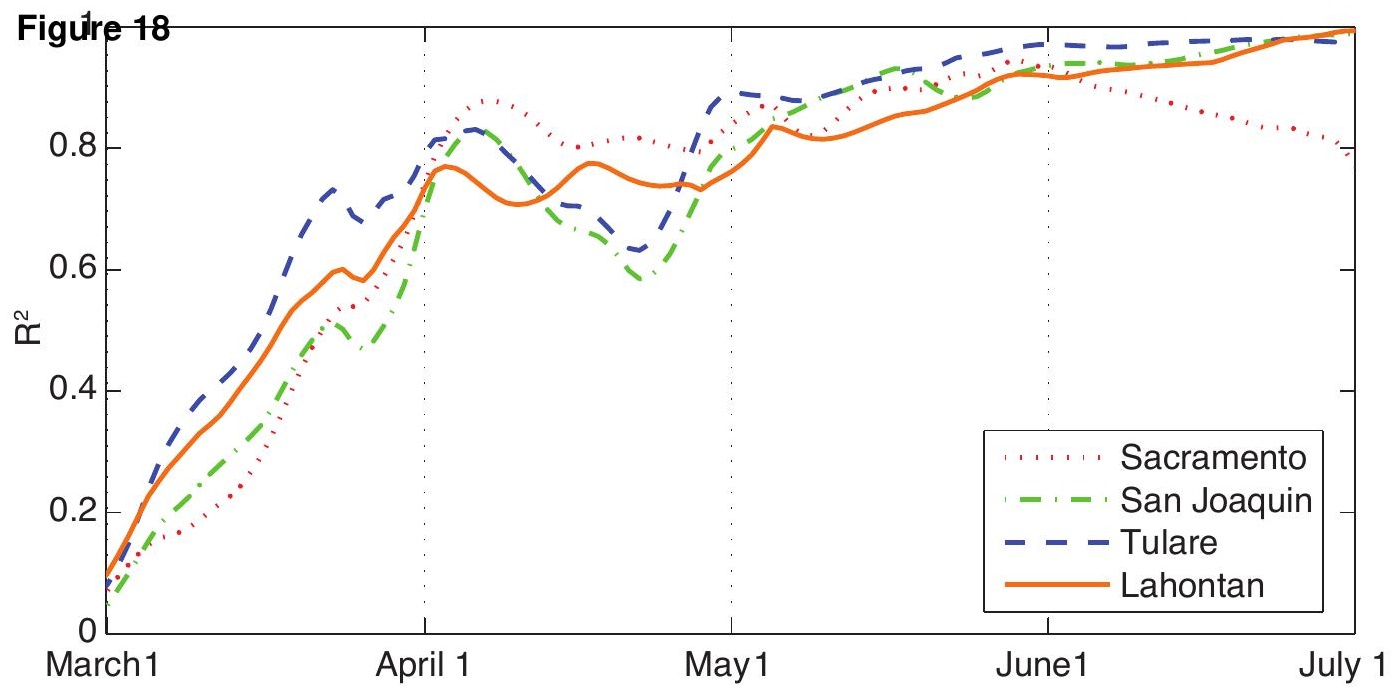

